\title{
La supresión de los pequeños municipios: régimen, alternativas, ventajas e inconvenientes
}

\author{
Manuel Rebollo Puig \\ Catedrático de Derecho Administrativo \\ Universidad de Córdoba ${ }^{1}$
}

Sumario: I. PANORAMA GENERAL. EL MAPA MUNICIPAL ESPAÑOL. 1. Proliferación en España de pequeños municipios. Comparación con la situación de Portugal. 2. La crítica general a la atomización municipal española y la aspiración a una drástica reforma.-2. LA CUESTIÓN PREVIA DE LA DISTRIBUCIÓN DE COMPETENCIAS ENTRE EL ESTADO Y LAS COMUNIDADES AUTÓNOMAS PARA LA ALTERACIÓN DE LOS MUNICIPIOS. - 3. RÉGIMEN DE LA ALTERACIÓN DE MUNICIPIOS; EN ESPECIAL, LAS VÍAS PARA SU SUPRESIÓN. 1. La legislación estatal básica sobre alteración de términos municipales. 2. Legislación estatal supletoria sobre alteración de términos municipales: en particular, sobre la supresión de municipios por incorporación o fusión. 3 . Legislación autonómica sobre alteración de términos municipales: en particular, sobre la supresión de municipios por incorporación o fusión. 4. Posibilidad de referéndum. 5. Del fomento y otras formas de dulcificar las incorporaciones y fusiones; en particular, la reencarnación del municipio extinto en una entidad inframunicipal o en un órgano desconcentrado. 6. Referencia a la creación de municipios..-IV. LA DOCTRINA DOMINANTE SEGÚN LA CUAL LA AUTONOMÍA LOCAL NO IMPIDE NI LIMITA LA SUPRESIÓN DE MUNICIPIOS. - V. NECESIDAD DE REPLANTEAR EL PROBLEMA Y LAS SOLUCIONES ANTE UNA SITUACIÓN CONSOLIDADA Y NO TAN TRÁGICA. 1. Las posiciones menos favorables a cambios drásticos del mapa municipal consolidado. 2. Los problemas de los pequeños municipios y los problemas derivados de otros factores. - VI. REPLANTEAMIENTO JURÍDICO: LÍMITES A LA SUPRESIÓN DE MUNICIPIOS. 1. La autonomía sí se ve afectada por la supresión y, aunque no la impide, pone límites a las decisiones de fusión e incorporación. 2. Control de la supresión de municipios para garantizar la autonomía local.-VII. ALTERNATIVAS A LA SUPRESIÓN DE MUNICIPIOS. 1. Régimen especial de organización y funcionamiento adecuado a los pequeños municipios. 2. La adaptación de las competencias a las posibilidades y necesidades de los pequeños municipios. 3. La cooperación con los pequeños municipios de las demás Administraciones, en particular de las provincias. 4. Colaboración y asociacionismo entre municipios. 5. Referencia particular a la Ley de Desarrollo Sostenible del Medio Rural. 6. Agrupaciones forzosas de municipios. 7. Réplicas y dúplicas sobre estas soluciones alternativas a la supresión..VII. REFLEXIONES FINALES.

\footnotetext{
1 Grupo de Investigación de la Junta de Andalucía SEJ 196. Proyecto del Ministerio SEJ 2007-66942. El presente trabajo tiene su origen en la ponencia presentada en el $8 .^{\circ}$ Congreso hispano-luso de Derecho Administrativo celebrado en Braga los días 5 y 6 de diciembre de 2008 bajo el título «Problemas actuales de la Administración municipal»; en concreto en la sesión dedicada a las «Posibilidades de reforma de las actuales estructuras municipales y su respectivo régimen jurídico».
} 


\section{PANORAMA GENERAL. EL MAPA MUNICIPAL ESPAÑOL}

\section{Proliferación en España de pequeños municipios. Comparación con la situación de Portugal}

España cuenta con algo más de 8.000 municipios muy distintos entre sí tanto en número de habitantes como en extensión. Pero en todo caso abundan los pequeños en población y en territorio. Del total, unos 7.000 tienen menos de 5.000 habitantes y casi un millar menos de un centenar de habitantes, repartidos de forma muy desigual en las distintas comunidades autónomas ${ }^{2}$. Por lo que se refiere a su extensión, hay grandes diferencias, no ya entre los de distintas comunidades autónomas, sino entre diferentes provincias. Por ejemplo, en Murcia los municipios tienen una superficie media de algo más de 250 $\mathrm{Km}^{2}$, en Andalucía de unos $115 \mathrm{Km}^{2}$, con municipios como el de Córdoba con $1.255,24 \mathrm{Km}^{2}$ (sólo algo menos que la provincia de Guipúzcoa que tiene 1.900); mientras que en el extremo opuesto, en la provincia de Barcelona la media de los términos municipales es de algo más de $25 \mathrm{Km}^{2}$ y en la de Vizcaya no llega a los $22 \mathrm{Km}^{2}{ }^{3}$. En esta superabundancia de municipios y en la consiguiente atomización nos diferenciamos bastante de Portugal, a la que bien podríamos señalar como un modelo. Es más, Portugal es precursora y adelantada de muchos Estados europeos pues, no habiendo tenido nunca un número desmesurado de municipios (a lo sumo llegó a tener unos 800), realizó hace mucho tiempo una drástica reducción, como siglo y medio después han hecho Alemania, Bélgica, Gran Bretaña, Holanda, Suecia, Grecia... aunque todos ellos con resultados más modestos que Portugal. Las bases de su mapa municipal se sentaron en $1.836 \mathrm{y}$, desde entonces, se han respetado escrupulosamente sus principios y racionalidad. De hecho, en algunos momentos se ha reducido notablemente el número de municipios y, en cualquier caso, ha sometido a criterios rigurosos la creación de nuevos municipios. Cuenta así con alrededor de 300 municipios, de los cuales sólo unos 40 tienen menos de 5.000 habitantes ${ }^{4}$. La diferencia con España es abismal y hasta ha sido mucho mayor

\footnotetext{
2 Vid. Luis ORTEGA ÁLVAREZ, «Diferenciación frente a uniformidad en la organización territorial local», Anuario del Gobierno Local, 1999/2000, págs. 77-78.

3 Ofrece unos cuadros muy interesantes sobre población y extensión de los municipios por comunidades autónomas y provincias Julio CASTELAO RODRÍGUEZ, El términos municipal. Extensión y alteraciones, Publicaciones Abella, Madrid, 1994, págs. 395 a 420. Puede verse una información completa y actualizada de cada uno de los municipios y de otros entes locales en página web del Ministerio de Administraciones Públicas www.map.es/documentación/entes_locales/registro_entidades_locales, donde se recoge el documento Entidades locales en España 2007.

4 Vid. Antonio Cândido de OliveIRA, «La organización municipal portuguesa: consolidación de la autonomía», Documentación Administrativa, n. ${ }^{\circ} 228$, octubre-diciembre de 1991, págs. 238-239; y, sobre todo, del mismo autor, «La creación de municipios en Portugal: las razones de un reciente veto del Presidente de la República. La importancia de la dimensión de los municipios para la consecución de una autonomía efectiva y para la adecuada prestación de los servicios públicos locales», Cuadernos de Derecho local, 9 de octubre de 2005 , págs. 65 y ss.
} 
a mediados del siglo XIX que fue cuando alcanzamos nuestro record ${ }^{5}$. En la actualidad, sólo la provincia de Burgos, que no llega ni remotamente al medio millón de habitantes, tiene bastantes más municipios que toda Portugal. Si Portugal padeciese el minifundismo municipal de España, multiplicaría por siete su actual número de municipios. Naturalmente no se les ocurrirá seguir esa senda ni nadie se atreverá ni en broma a sugerirla. Más bien, es España la que puede mirar con envidia esa organización municipal portuguesa y la legislación que la ha hecho posible y que la mantiene. Podríamos decir que, ante el problema de los pequeños municipios, hemos actuado de forma diferente según nuestras distintas tradiciones taurinas: los portugueses, como sus força$d o s$, «han cogido el toro por los cuernos»; los españoles nos hemos dedicado a torear el problema.

\section{La extendida crítica a la atomización municipal española y la aspiración a una drástica reforma}

Con ese censo de municipios no es de extrañar que haya un amplio consenso al afirmar que hay en España demasiados municipios y demasiado pequeños y una extendida opinión sobre la necesidad de una drástica reforma. Se parte normalmente de que la existencia de municipios pequeños es una grave patología que comporta todo género de males sin mezcla de bien alguno. Entre otras cosas, impide que los ciudadanos cuenten con los servicios públicos adecuados, dificulta la existencia de una auténtica y efectiva autonomía local y genera todo tipo inconvenientes para atribuir competencias a los entes locales. Así, en suma, se les considera nocivos para el minimunicipio mismo y para sus habitantes, así

\footnotetext{
5 Según los datos que ofrece Enrique ORDUÑA REBOLLO, «Nuevas aportaciones sobre el mapa municipal español», Revista de Estudios de la Administración Local, n. ${ }^{\circ} 291$ (2003), en el año 1842 había 11.271 municipios y es posible que en algún momento anterior la cifra fuera algo más alta (11.415). Más difícil es saber exactamente a qué se debió esta proliferación. Generalmente se imputa a la Constitución de Cádiz y a su supuesto seguimiento del modelo revolucionario francés. Pero debe notarse, de un lado, que la propuesta provino de los diputados americanos que pensaban en las grandes distancias entre las poblaciones de aquel continente y, por otra parte, que realmente la Constitución de 1812 sólo imponía municipios cuando hubiera más de mil almas de modo que más bien se presentaba como excepcional la existencia de municipios menores. Eso es muy distinto de la fórmula francesa: «il y aura une municipalité en chaque ville, bourg, paroise ou communauté de campagne». De otra parte, el mismo ORDUÑA, cit., pág. 787, da un dato que obliga a reflexionar cuando afirma, aun con todo el convencionalismo que se quiera, que en el periodo final del Antiguo Régimen había «12.000 entidades de población que reunían las condiciones de gobierno local características de un municipio». Así que podría pensarse, tal vez, que en el siglo XIX sólo se dio forma de municipio a lo que ya era algo similar. Con todo, sí parece cierto que bajo la vigencia del Decreto de 23 de mayo de 1812, del de 23 de junio de 1813 y del 3 de febrero de 1823 se crearon muchos municipios de menos de 1.000 habitantes y que parecía verse en ello la forma de liberar a los pueblos de la jurisdicción señorial y de establecer un sistema uniforme de Administración frente a la compleja organización anterior, plagada de privilegios y singularidades territoriales. Vid. Sebastián MARTín-RETORTILLO y Enrique ARGULLOL, en la obra colectiva dirigida por el primero Descentralización administrativa y organización política, Tomo I, «Aproximación histórica (1812-1931)», Alfaguara, Madrid, 1973, págs. 25, 50-51; y Javier GARCíA FERNÁNDEZ, El origen del municipio constitucional, IEAL, Madrid, 1983, págs. 266-267. No hay, sin embargo, datos exactos de los municipios que se crearon ni de los existentes hasta 1842, momento a partir del cual empezó a disminuir, como luego se recordará.
} 
como para el sistema en su conjunto ${ }^{6}$. La crítica viene de antiguo ${ }^{7}$ y se mantiene con fuerza en la actualidad ${ }^{8}$. Entre las últimas más brillantes y hasta vibrantes pueden traerse aquí las de los Profesores Parada Vázquez y Sosa Wagner. El primero habla de «anacrónico mapa municipal», de «miles de municipios fantasmales», todo fruto, como en Francia, de un «accidente catastrófico debido al talento demagógico de Mirabeau». Y pone el énfasis en que los males que comportan esos municipios ínfimos se han agravado recientemente, no sólo por las nuevas circunstancias sociales, sino por las jurídicas, al proclamarse más radicalmente su autonomía y haber disminuido considerablemente los controles de otras Administraciones 9 . No le va a la zaga el profesor Sosa que clama y reclama ante esta situación: clama contra los «municipios que no conservan de tales nada más que el nombre, convertidos ... en fantasmas de Administraciones, sin población, sin servicios, sin recursos»; y reclama una «operación de cirugía» con la «necesaria desaparición de muchos ayuntamientos, en rigor, espectros incapaces de proyectar sombra alguna de consistencia» ${ }^{10}$. Como se notará, las referencias a los fantasmas son reiteradas y expresivas. En el mapa municipal

6 La misma o similar crítica es habitual en la doctrina de otros países y, de hecho, está en la base de las grandes reformas que han realizado muchos de ellos, a las que luego se aludirá. Y también lo es en Francia donde no se ha procedido a esa reforma. Baste para probarlo aquí la cita de Jean de SAVIGNY, ¿El Estado contra los municipios?, traducción al castellano de José BERMEJO VERA, IEAL, Madrid, 1978, págs. 224 a 229. Allí se acusa a la fragmentación municipal de ser «causa del debilitamiento del poder de los municipios», «peligro para la vitalidad de los poderes locales», justificación para la «transferencia de funciones hacia el Estado», «obstáculo en orden a la racional localización de los equipamientos» y «organización de los servicios públicos», «perjudicial para la eficacia administrativa y la justicia fiscal», impedimento para la «planificación del desarrollo» y hasta motivo de degradación de la democracia que «sale maltratada» porque «se continúa designando con gran solemnizad a los representantes municipales, pero el poder se encuentra en otra parte».

7 Vale la pena para atestiguarlo la cita de algunos fragmentos de la presentación del Proyecto de Ley de 2 de noviembre de 1860 de Posada Herrera, a la sazón Ministro de Gobernación: «No es necesaria una larga práctica administrativa para conocer los graves inconvenientes que ofrecen esas municipalidades microscópicas, como son muchas las que hoy existen, y que más bien que agregaciones de carácter público, pueden considerarse como familias dilatadas. Sin recursos para cubrir sus más perentorias atenciones, sometidas ciegamente a la influencia del vecino más rico o más astuto o menos ignorante, que la ejerce por lo común en provecho propio, agobiadas por la carga de un presupuesto superior a sus fuerzas, imposibilitadas de rodearse, por falta de medio para dotarlos decorosamente, de auxiliares inteligentes que los ilustren y aconsejen en la gestión de sus negocios y en sus relaciones con los delegados superiores del Gobierno, estos Ayuntamientos, no sólo son una rémora constante para la Administración en general, sino incapaces de llenar el objeto propio de una asociación de su índole». Tomo la cita de Enrique ORDUÑa REBOLlO y Luis CosculLuELA MONTANER, Historia de la legislación de Régimen Local, Iustel, Madrid, 2007, pág. 769.

8 Vid. Tomás Ramón FernándeZ, Entre el Derecho y la política, Madrid, 1987, págs. 122 a 124, que pide una reforma que «elimine la farsa de las 8.500 Administraciones públicas actuales, cuya existencia ... sólo sirve para alimentar el mito de la incapacidad de los entes locales y la ineficacia de los esquemas descentralizadores».

9 J. Ramón PARADA VÁZQUEZ, La segunda descentralización: del Estado autonómico al municipal, Thomson/Civitas, Madrid, 2007, págs. 36 y ss.; 85 y ss.; y 119 y ss.

10 Francisco SosA WAGNER, en el «Prólogo para españoles» al libro de Luciano VANDELLI, Trastornos de las instituciones políticas, Trota/Fundación Alfonso Martín Escudero, Madrid, 2007, pág. 26. En la misma línea, aunque más moderadamente, Juan JUNQUERA GONZÁLEZ, «La reforma y la modernización de la Administración Local española», en Fernando SAINZ MORENO (Dir.), Estudios para la reforma de la Administración pública, INAP, 2004, págs. 334 a 336; y José Luis MARTíNEZ LÓPEZ-MuÑIZ, «Cooperación y subsidiariedad intermunicipal», Revista de Estudios de la Administración Local y Autonómica, n. 302 (206), págs. 66 y 67. 
español, «en ocasiones, veo muertos». Así que, según parece, ya no hay que matarlos, sólo certificar su defunción y enterrarlos.

Con estos diagnósticos generalmente aceptados, lo que me corresponde aquí es exponer cómo acabar con ese minifundismo municipal o cómo reducirlo y, en concreto, cómo hacerlo conforme al Derecho español. O sea, cómo cazar a esos fantasmas, cómo enterrar a esos muertos vivientes. Así lo haré de inmediato para cumplir con el encargo que se me ha hecho por los organizadores de este $8 .^{\circ}$ Coloquio luso-español, a los que aprovecho para agradecer su esfuerzo del que tanto nos beneficiamos los profesores españoles por el enriquecedor contacto con los profesores portugueses. Pero aclaro ya que tengo algunas reservas frente a ese planteamiento, que existen algunas alternativas distintas de la pura y dura supresión de municipios y que, para muchos supuestos, pueden resultar preferibles; que quizás lo que se quiera no sea enterrar muertos sino una especie de eutanasia municipal a gusto del ejecutor. Dejemos esto para luego.

\section{LA CUESTIÓN PREVIA DE LA DISTRIBUCIÓN DE COMPETENCIAS ENTRE EL ESTADO Y LAS COMUNIDADES AUTÓNOMAS PARA LA ALTERACIÓN DE LOS MUNICIPIOS}

La distribución de competencias entre el Estado y las comunidades autónomas respecto a las Administraciones locales se ha resuelto en aplicación del art. 149.1.18 ${ }^{\text {a }}$ CE. En este precepto no se habla ni de competencias sobre régimen local ni sobre entes locales. Atribuye al Estado «las bases del régimen jurídico de las Administraciones públicas»; pero, en tanto que los entes locales son precisamente Administraciones públicas, también corresponden al Estado las bases del régimen local. Y eso incluye, no ya sólo dictar unas bases comunes para todas las Administraciones públicas, sino también unas específicas para las Administraciones locales. Las comunidades autónomas tendrán competencia sobre el resto de la legislación local y sobre toda la ejecución ${ }^{11}$.

Pero en ese conjunto, la CE singulariza un aspecto o submateria: su art. 148.1.2..$^{\circ}$ permite a todas las comunidades autónomas y desde el mismo momento de su creación asumir la competencia relativa a «las alteraciones de los términos municipales comprendidos en su territorio». Así que «las alteraciones de los términos municipales» están más claramente incardinadas en las compe-

\footnotetext{
11 Aclaremos por el foro en que nos encontramos que es una solución discutida. Hay quien sostiene que no sólo es que la CE permita que el régimen local pase a la entera y exclusiva competencia autonómica sino que sería lo más correcto. Algunos de los nuevos Estatutos de autonomía van más o menos en esa dirección. Pero no es ocasión de adentrarnos en ello. Para nuestro propósito aquí podemos aceptar que la CE otorga al Estado la legislación básica de régimen local y a las comunidades autónomas el resto de la legislación más toda la ejecución. De hecho, esa interpretación de la Constitución es la que ha asumido el Tribunal Constitucional y la que sustenta la existencia de la Ley estatal Reguladora de las Bases del Régimen Local.
} 
tencias autonómicas. No sólo lo justifica el art. 148.1.2. ${ }^{\circ} \mathrm{CE}$, sino que es una solución acorde con la naturaleza de la cuestión pues se considera generalmente que la perspectiva y el nivel autonómicos son los más adecuados para abordar la ordenación territorial municipal, máxime teniendo en cuenta que a este respecto la realidad española es bastante diferente de unas regiones a otras ${ }^{12}$. Podría mantenerse entonces que en lo que se refiere a este específica cuestión del régimen local, ni siquiera caben bases estatales ${ }^{13}$. Pero el TC terminantemente acogió otra interpretación en la sentencia 214/1989, de 21 de diciembre, fundamento jurídico 8:

«... en relación a las alteraciones municipales, sin perjuicio de lo dispuesto en el art. 148.1 y 2 CE, el Estado ostenta también competencia para fijar los criterios básicos a los que debe sujetarse el ejercicio de las correspondientes competencias autonómicas, y ello como resultado del juego combinado de los arts. 137, 140 y 149.1.18 ${ }^{\text {a }} \mathrm{CE}$, que obligan necesariamente a atribuir al Estado la regulación básica de su propia estructura».

Y no sólo es que permitiera al Estado regular las bases de la creación, supresión y alteración de municipios. Es que además aceptó concretamente las bases aprobadas por el Estado sobre estos extremos ${ }^{14}$. Por tanto, podemos aquí aceptar las modestas bases que el Estado ha fijado a este respecto. Adelantemos que dejan a las comunidades autónomas un amplio margen para acometer una intensa política de supresión de pequeños municipios ${ }^{15}$.

12 Incluso se vio en esa competencia autonómica una especial oportunidad de reforma del mapa municipal. Vid. Antonio EMBID IRUJO, «Autonomía municipal y Constitución: aproximación al concepto y significado de la declaración constitucional de la autonomía municipal», Revista Española de Derecho Administrativo, n. ${ }^{\circ}$ 30, pág. 466. Y se sigue manteniendo que las diferencias entre la estructura territorial de unas y otras Comunidades justifica la competencia regional en la materia. Vid. Albert PEREIRA I SOLÉ, «El régimen local en la reforma del Estatuto de Autonomía de Cataluña», Anuario del Gobierno Local, 2004, pág. 201.

13 De hecho, algunos de los nuevos Estatutos de Autonomía se orientan en esa dirección. Establecen una nítida distinción entre dos competencias: las relativas a «organización territorial», que incluiría la creación, supresión y alteración de municipios y que sería competencia exclusiva de las comunidades autónomas; y las de régimen local, en que se respetaría la competencia estatal sobre las bases. Por ejemplo, arts. 59 y 60 del nuevo Estatuto andaluz. Sin embargo, la situación se salva en el art. 91.2 del propio Estatuto. Vid. José Luis RIVERo YSERn, «El régimen local en el nuevo Estatutos de Autonomía de Andalucía. Reglas sustantivas y distribución de competencias», en Santiago MuÑoz MaCHADO y Manuel RebOLLO PUIG (Dirs.), Comentarios al Estatuto de Autonomía para Andalucía, Thomson/Civitas, Madrid, 2008, págs. 847 y ss.

14 Así se lee en esa STC 214/1989, de 21 de diciembre: «... no resulta en absoluto ilegítimo constitucionalmente, ni, por tanto, vulnerador de la competencia autonómica, que el Estado, con cobertura en el art. 149.1.18. ${ }^{\mathrm{a}} \mathrm{CE}$, haya establecido esa exigencia mínima». Se refiere el TC en ese pasaje a la exigencia para crear nuevos municipios de un «núcleo separado de población»; pero lo mismo se puede decir de los otros requisitos establecidos en la ley básica estatal, que ahora expondremos. De hecho, de inmediato añade la STC que si bien es cierto que el Estado en su ley básica «irrumpe ... en el campo de la organización territorial, es incuestionable que con ello no se ha excedido de la competencia que, con cobertura en el art. 149.1.18. ${ }^{\mathrm{a}} \mathrm{CE}$, puesto en relación con los arts. 137 y 140 de la misma norma fundamental, le corresponde a fin de regular los requisitos que con carácter necesario deben reunir los municipios».

15 Vid. Catalina ESCUÍN PALOP, «La alteración de términos municipales», en Santiago MuÑOZ MACHADO

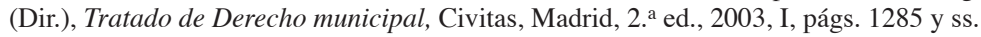




\section{RÉGIMEN DE LA ALTERACIÓN DE MUNICIPIOS; EN ESPECIAL, LAS VÍAS PARA SU SUPRESIÓN}

\section{La legislación estatal básica sobre alteración de términos municipales}

La Ley Reguladora de las Bases del Régimen Local de 1985 (en lo sucesivo, LRBRL) se ocupa de nuestra cuestión fundamentalmente en su art. 13 que es del siguiente tenor:

Art. 13. 1. La creación o supresión de Municipios, así como la alteración de términos municipales, se regulará por la legislación de las Comunidades Autónomas sobre régimen local, sin que la alteración de términos municipales pueda suponer, en ningún caso, modificación de los límites provinciales ${ }^{16}$. Requerirá en todo caso audiencia de los Municipios interesados y dictamen del Consejo de Estado o del órgano consultivo superior de los Consejos de Gobierno de las Comunidades Autónomas, si existiere. Simultáneamente a la petición de este dictamen se dará conocimiento a la Administración General del Estado.

2. La creación de nuevos Municipios sólo podrá realizarse sobre la base de núcleos de población territorialmente diferenciados y siempre que los Municipios resultantes cuenten con recursos suficientes para el cumplimiento de las competencias municipales y no suponga disminución en la calidad de los servicios que venían siendo prestados.

3. Sin perjuicio de las competencias de las Comunidades Autónomas, el Estado, atendiendo a criterios geográficos, sociales, económicos y culturales, podrá establecer medidas que tiendan a fomentar la fusión de Municipios con el fin de mejorar la capacidad de gestión de los asuntos públicos locales.

Por tanto, lo único que impone el Estado a las comunidades autónomas en cuanto a la supresión de municipios son requisitos puramente formales entre los que destaca la audiencia de los municipios interesados. Este requisito procedimental se considera, además, expresión o consecuencia misma de la autonomía municipal, como refleja bien la Carta Europea de la Autonomía Local (del Consejo de Europa de 15 de octubre de 1985, inmediatamente posterior a la LRBRL y ratificada por España mediante Instrumento de 20 de enero de 1988; en lo sucesivo CEAL) en cuyo texto sólo el art. 5 afecta directamente a lo que nos ocupa y que bajo el rubro «protección de los límites territoriales de las entidades locales» se limita a exigir que sean consultadas previamente.

16 La parte en cursiva se añadió en la reforma operada por la Ley 57/2003, de 16 de diciembre, y es trasunto de las prescripción del art. 141.1 CE, a la que ya nos referimos antes, según la cual «cualquier alteración de los límites provinciales habrá de ser aprobada por las Cortes Generales mediante ley orgánica». Vid. Rafael Pizarro Nevado, Comentario al artículo 13, en Comentarios a la Ley Reguladora de las Bases del Régimen Local, op. cit., I, pág. 267. 
Además, la misma LRBRL establece que, dentro de cada Ayuntamiento, el órgano competente para pronunciarse sobre estos extremos es el Pleno [art. 22.2.b)] que debe hacerlo por mayoría absoluta del número legal de miembros de las Corporación [art. 47.2.a) $]^{17}$.

\section{Legislación estatal supletoria sobre alteración de términos municipales: en particular, sobre la supresión de municipios por incorporación o fusión}

Junto a esta legislación básica, la única que se impone a las comunidades autónomas, el Estado conserva una legislación supletoria sobre alteraciones de los municipios. Se contiene, de un lado, en el Texto Refundido de las Disposiciones Legales Vigentes en materia de Régimen Local (TRRL) aprobado por Real Decreto Legislativo 781/1986, de 18 de abril (en concreto, arts. 3 a 9); de otro en el Reglamento de Población y Demarcación Territorial de las (RPDT) aprobado por Real Decreto 1690/1986, de 11 de julio (arts. 2 a 16). El interés de esta legislación supletoria estatal está, más que en su aplicabilidad, que ya es reducida pues gran parte de las comunidades autónomas tiene legislación propia sobre la materia, en que ofrece una panorama general y unos términos que han influido en la legislación autonómica. Sinteticemos sus aspectos más relevantes.

\section{Modalidades de alteración municipal}

Se distinguen cuatro posibilidades dentro de la alteración de términos municipales $^{18}$ :

1. ${ }^{a}$ La incorporación de un municipio a otro. Es, evidentemente, una forma de suprimir un municipio sin crear ninguno nuevo pues un muni-

\footnotetext{
17 Inicialmente, la redacción originaria de la LRBRL exigía una mayoría aún mayor: «voto favorable de las dos terceras partes del número de hecho y, en todo caso, de la mayoría absoluta del número legal de miembros de la Corporación». Desde la Ley 57/2003, que modificó la LRBRL, basta la mayoría señalada en el texto. Muchas leyes autonómicas siguen formalmente exigiendo esa mayoría de dos tercios, para hay que entenderlas superadas tras la reforma de la LRBRL. Cabría sostener que esa regulación autonómica subsiste tras la reforma de la LRBRL si se entendiera que no la contradice, que la ley básica sólo establece un mínimo que no impide que las comunidades autónomas refuercen. Pero no creo que sea así: con su reforma, la LRBRL garantiza la posibilidad de decidir ciertos asuntos por mayoría absoluta y no creo que ahora quepa que una ley autonómica pueda requerir mayorías superiores para ningún asunto. Si se acepta esto, hay que entender desplazadas las leyes autonómicas anteriores a la Ley 57/2003 que siguen imponiendo la mayoría de dos tercios. Vid. Eloisa CARBOnELl PORRAS, Comentario al artículo 47 en la obra dirigida por Manuel REBOLLO PUIG y coordinada por Manuel Izquierdo Carrasco, Comentarios a la Ley Reguladora de las Bases de Régimen Local, cit., II, págs. 1183 y ss.

18 Así es como aparecen tradicionalmente la supresión y creación de municipios pues, como explica Rafael ENTRENA Cuesta, «La agregación de municipios», en Problemas políticos de la vida local, Madrid, 1964, tomo IV, pág. 285, dado que toda la superficie del territorio nacional se encuentra dividida en términos municipales, la teoría del nacimiento, modificación y extinción de los municipios se reconduce al estudio de la alteración del territorio de éstos...».
} 
cipio ya existente y que subsiste como tal absorbe a otro que desaparece. Puede tratarse de la incorporación de varios municipios, no de uno solo, a otro.

2. a) La fusión de dos o más municipios. También en este caso se suprimen municipios pues todos los que son objeto de esta operación desaparecen y se crea uno nuevo que sustituye a todos los preexistentes.

3. ${ }^{a}$ La segregación de parte de un municipio para constituir uno nuevo. Aquí no hay reducción del número de municipios sino aumento. Puede suceder que la segregación afecte a varios municipios y que con partes del territorio de todos ellos se constituya un nuevo municipio, pero nunca desaparece ninguno de los municipios preexistentes.

4. ${ }^{a}$ ) La simple alteración de los límites municipales que se consigue con la anexión de parte de un municipio a otro. En este caso ni se crea ni se suprime ningún municipio sino que simplemente cambian sus territorios y límites. Las normas también llaman a esto segregación pero es preferible prescindir de ese término para evitar confusión con la operación anterior que es la que merece ser llamada más propiamente así.

Aquí nos interesan sobre todo la incorporación y la fusión, que son las operaciones que pueden servir a esa finalidad de reducción de municipios que nos ocupa. Cierto que formalmente también en la fusión nace un nuevo municipio pero es claro que el sentido general de esta actuación es el de reducir el número de municipios y suprimir los pequeños. De la segregación sólo nos ocuparemos para buscar referencias que nos sirvan para configurar la visión general del legislador sobre el mapa municipal. Y podemos prescindir por completo de la simple alteración de términos municipales.

En realidad, esta legislación supletoria no perfila exactamente cuándo procede la incorporación y cuándo la fusión, siendo en principio dos figuras que sirven a la misma finalidad. Pero en el fondo late lo que ya expresamente sí han consagrado algunas normas autonómicas: que la incorporación procede cuando de entre los municipios afectados hay uno mayor o preponderante; y que la fusión, por el contrario, es la solución en los casos en los que todos los municipios presentan características de población y riqueza similares ${ }^{19}$. Pero, aun así, queda un margen notable para optar por la incorporación o por la fusión en virtud de las específicas circunstancias que se presenten en cada situación.

\footnotetext{
19 Por ejemplo, arts. 6.2 y 8 del Reglamento de Territorio y Población de las Entidades Locales de Aragón: «Procederá la incorporación cuando exista un municipio que cuente con mayor potencial demográfico y económico y disponga de los medios personales y materiales para hacerse cargo de la gestión de los servicios del conjunto de la población y territorio resultante de la incorporación. En otro caso, procederá la tramitación de la fusión de municipios»; «procederá la fusión... siempre que el potencial demográfico y económico de los municipios interesados sea similar». En parecidos términos, por ejemplo, art. 7.2 del Reglamento de Demarcación Territorial y Población de los Entes Locales de Cataluña.
} 


\section{Presupuesto de hecho para la supresión de municipios}

Esta legislación estatal supletoria no precisa el presupuesto de hecho necesario para la incorporación. El TRRL sólo dice que «la incorporación de uno o más municipios a otros u otros limítrofes solamente podrá acordarse cuando se den notorios motivos de necesidad o conveniencia económica o administrativa» $(\text { art. } 4)^{20}$. De aquí lo único que se deduce es que es una operación que se configura como excepcional pese a lo cual queda una relativamente amplia discrecionalidad para acometerla.

Algo más explícita es esta legislación al establecer algunos de los presupuestos de hecho que autorizan la fusión de municipios. Puede realizarse, según el art. 5 TRRL, en estos casos:

a) Cuando separadamente carezcan de recursos suficientes para atender los servicios mínimos exigidos por la Ley.

b) Cuando se confundan sus núcleos urbanos como consecuencia del desarrollo urbanístico.

c) Cuando existan notorios motivos de necesidad o conveniencia económica o administrativa ${ }^{21}$.

Pero si el a) y el b) pueden considerarse más o menos acotados, el presupuesto de la letra c) es tan impreciso y evanescente como el que hemos visto para la incorporación.

En todo caso es seguro que la concurrencia de cualquiera de estos presupuestos fácticos simplemente permite la alteración correspondiente, pero no impone el deber de acordar la fusión o incorporación.

\section{Posibilidad de incorporación y de fusión en contra de la voluntad de los municipios. Resolución por Decreto regional}

Lo más relevante de esta legislación estatal supletoria es que tanto para la incorporación como para la fusión admite que el procedimiento se inicie de oficio por la correspondiente comunidad autónoma y en todos los casos termina por Decreto de su Consejo de Gobierno ${ }^{22}$. Por tanto, todas estas operaciones se pue-

\footnotetext{
20 El art. 4.1 RPDT añade que también cabe la incorporación cuando «lo imponga la mejora de la capacidad de gestión de los asuntos públicos locales». Sin negar lógica a esta demasiado etérea expresión, resulta excesivo que un simple reglamento haya previsto otro supuesto de incorporación no establecido en la norma con rango de ley, máxime teniendo en cuenta que se afecta directamente a la autonomía local. Vid. Julio CASTELAO RODRÍGUEZ, El términos municipal. Extensión y alteraciones, cit., págs. 80 y ss.

21 Vid. Julio CASTELAO RodRÍGUEZ, El términos municipal. Extensión y alteraciones, cit., págs. 102 y ss.

22 Ello, sin embargo, con la excepción del País Vasco donde la competencia corresponde a las Diputaciones Forales de sus Territorios Históricos, como reconoció la STS de 3 de mayo de 2004 (Arz. 2559).
} 
den llevar a cabo en contra de la voluntad de los municipios afectados. Sólo hay que darles audiencia, tal y como ya impone la LRBRL y la CEAL, pero su informe contrario no condiciona el sentido de la resolución. Y en todo caso se puede llegar a decidir la incorporación o fusión sin necesidad de ley, es decir, sin intervención del Parlamento regional ${ }^{23}$. Pero, pese a esto, no creo que pueda excluirse que cada vez que el Parlamento regional lo desee, pueda aprobarse la fusión o la incorporación por ley. Entonces el problema será el de los límites de esa ley y el de su control. Es decir, ¿podrá fusionar o incorporar municipios esa ley sin cumplir los requisitos establecidos con carácter general? ¿podrá hacerlo incluso sin justificar una verdadera necesidad de interés general? Y, si la respuesta es negativa ¿quién y cómo se contrala esa ley?. Pero eso nos ocupará luego.

La adición procedimental más significativa respecto a las previsiones de la LRBRL es que, además de informe del Consejo de Estado u órgano similar de la comunidad autónoma, es necesario el de la respectiva diputación provincial que tampoco es vinculante. Así mismo se prevé como necesario el trámite de información pública.

Conste que también se admite la posibilidad de que estos procedimientos se inicien a instancia, no sólo de la Administración del Estado o de la diputación provincial, sino incluso de los ayuntamientos interesados o que sean tramitados con carácter voluntario comenzando por acuerdos de los ayuntamientos. Pero es menos que improbable que los ayuntamientos, sus alcaldes y concejales, decidan hacerse el harakiri. No abundaremos por ello en esta posibilidad teórica que, además, no exime de una resolución final por Decreto.

\section{Sucesión de municipios; en especial, cambio en los órganos municipales}

Por lo demás, el RPDT se ocupa con cierto detalle de los complejos problemas que surgen en la transición en cuanto a los órganos de gobierno, bienes,

\footnotetext{
23 En contra se ha pronunciado José Luis RIVERo YSERN, Manual de Derecho Local, Thomson/Civitas, Madrid, 5. ${ }^{\text {a }}$ ed., 2004, pág. 108 que, pese a lo que establece el TRRL, entiende que la autonomía local exige en todo caso o, al menos, cuando haya oposición municipal, la aprobación de las fusiones y segregaciones por ley : «... la garantía institucional de la autonomía local reclama efectivamente la intervención de los Parlamentos regionales. Ello es consecuencia no sólo del necesario respeto a la libre decisión de las colectividades afectadas (lo que llevaría a reducir la intervención parlamentaria a los supuestos de disconformidad de los municipios afectados con la alteración), sino - insistimos - de la propia garantía constitucional de la autonomía local, lo que lleva a garantizar la intervención parlamentaria en todo supuesto de creación o extinción de municipios...». Pero esta interesante tesis no ha sido acogida por la jurisprudencia. Sólo en el caso de su sentencia de 30 de mayo de 1989 (Arz. 4096) nos consta que el Tribunal Supremo haya exigido Ley del Parlamento regional pese a que la legislación aplicable era la supletoria estatal: anuló el Decreto del Consejo de Gobierno de Murcia por el que se creaba un municipio por entender que era necesaria la aprobación del Parlamento de esa región; pero ello deduciéndolo, no como una consecuencia de la autonomía municipal, sino de unos determinados preceptos del Estatuto de Murcia que ya ni siquiera están vigentes. Vid. Rafael BARRANCO Vela, Creación y segregación de municipios, Marcial Pons, Madrid, 1993, págs. 280 a 283. Como luego se verá, esta tesis, que no he visto acogida por otros autores, sí se deja sentir en algunas legislaciones autonómicas. Pero, en cualquier caso, también hay otras normas autonómicas para las que, como en el Derecho estatal supletorio, basta Decreto del Consejo de Gobierno, incluso aunque haya oposición municipal. Luego se desarrollará en el texto.
} 
deudas... ${ }^{24}$. Interesa destacar que, en cuanto a los órganos de gobierno, se establece que los alcaldes y concejales de los municipios extintos pierden de inmediato su condición y, si acaso, eventualmente, pueden llegar a ser nombrados vocales gestores del municipio al que se incorporan o que resulte de la fusión.

\section{Inexistencia de una figura de reorganización general}

Una última precisión sobre esta legislación: no hay prevista una vía para una reorganización general o de gran alcance de la organización territorial municipal sino más bien operaciones concretas que eventualmente, como máximo, pueden afectar a ciertas zonas en su conjunto. Esto sólo se intuye al regular la incorporación pues nótese que se habla de «la incorporación de uno o más municipios a otro u otros...». Pero, aun así, se trata siempre de actuaciones limitadas, no de operaciones generales de reestructuración municipal.

\section{Legislación autonómica sobre alteración de términos municipales: en particular, sobre la supresión de municipios por incorporación o fusión}

Con la perspectiva que nos ha suministrado la exposición general de la legislación estatal supletoria, podemos referir ahora los aspectos más significativos de la legislación autonómica.

\section{Modalidades de alteración municipal}

Con pequeñas variaciones nominales y de sistematización, todas las leyes autonómicas contemplan los mismo cuatro tipos de alteraciones municipales que hemos visto en la legislación estatal y, en concreto, las dos formas de supresión - incorporación y fusión - que centran nuestro análisis.

\section{Presupuesto de hecho para la supresión de municipios}

Se tiende a concretar, más que propiamente a aumentar, los casos en que cabe la incorporación o fusión de municipios. Entre los ejemplos que podrían traerse, testimonia bien esta tendencia la Ley de Administración Local de La Rioja:

Art. 10. Supuestos de incorporación o fusión de municipios.- La incorporación o fusión de municipios podrá realizarse concurriendo alguna de las siguientes circunstancias:

24 Vid. Rafael Barranco Vela, Creación y segregación de municipios, cit., págs. 300 y ss.; y Catalina ESCUÍN PALOP, «La alteración de términos municipales», cit., págs. 1310 y ss. 
a) Cuando, como consecuencia del desarrollo urbano, se unan los respectivos núcleos de población ${ }^{25}$. Si alguno de los municipios tuviera varios núcleos, la unión deberá referirse al núcleo de mayor población o donde radique la capitalidad.

b) Cuando separadamente carezcan de los recursos necesarios para la prestación de los servicios mínimos obligatorios ${ }^{26}$.

c) Cuando, por despoblamiento, sea inviable el mantenimiento de una administración pública autónoma o carezca de justificación la reserva del disfrute de determinados aprovechamientos de titularidad pública por un grupo de población muy reducido 27 .

d) Cuando no exista voluntad efectiva de autogobierno, puesta de manifiesto por la falta de presentación de candidaturas en las elecciones municipales o por la ausencia de funcionamiento del régimen de Concejo abierto ${ }^{28}$.

e) Cuando existan otros motivos de interés general, debidamente fundados.

En diversas leyes autonómicas se incluye el supuesto de «descenso acusado y progresivo de su población» ${ }^{29}$, sin más requisitos; o el de disminución sustancial del territorio como consecuencia de obras públicas ${ }^{30}$. Pero en ningún caso se ha establecido un criterios simplemente cuantitativo, como el que se ha propuesto en algún caso de suprimir todos los municipios de menos de 500 habitantes o, siquiera, de $100^{31}$.

Cabe intentar agrupar todas estos presupuestos de hecho en dos grandes categorías: aquéllos que denotan la desaparición del sustrato social propio de un municipio; y aquellos otros que se refieren a su incapacidad económica o de gestión. Pero junto a ellos, puede haber otros que justifiquen la existencia de esos motivos indefinidos de interés general. Aquí ni siquiera puede decirse que las normas acoten un supuesto de hecho, aunque sea de forma imprecisa.

25 En algunas leyes autonómicas se denomina a esto incorporación o fusión por «confusión»; así, art. 9 de la Ley andaluza de Demarcación; art. 13 de la Ley de Régimen Local de Castilla y León.

26 Algunas comunidades matizan este presupuesto; por ejemplo en la Ley andaluza de Demarcación se habla de «falta de recursos para prestar, cada uno de ellos, por sí o asociados, los servicios mínimos...». El art. 5 de la Ley castellano-manchega de Entidades Locales reduce el supuesto a que los municipios no puedan prestar esos servicios mínimos «y no hayan solicitado la dispensa a que hace referencia el número 2» del art. 26 LRBRL. El art. 8.3 del Reglamento de Demarcación Territorial y Población de los Entes Locales de Cataluña se refiere al caso en el que «la mayoría de los servicios mínimos ha sido objeto de dispensa o son prestados por entes supramunicipales por vía supletoria».

27 El art. 8.3 del Reglamento de Demarcación Territorial y Población de los Entes Locales de Cataluña cuantifica el supuesto: «Municipios que tienen un número de habitantes inferior a 250».

28 Según la Ley de Castilla-La Mancha cabe la supresión de un municipio cuando no haya listas electorales ni se pueda constituir una comisión gestora.

29 Art. 13 de la Ley de Régimen Local de Castilla y León; 9 de la Ley andaluza de Demarcación.

30 Art. 9 de la Ley andaluza de Demarcación Municipal.

31 Juan JUNQUERA GONZÁLEZ, «La reforma y la modernización de la Administración Local española», en Fernando SAINZ MORENO (Dir.), Estudios para la reforma de la Administración pública, cit., págs. 335- 336. 
Igual que en la legislación estatal supletoria, la concurrencia de cualquiera de los presupuestos referidos permite la alteración correspondiente, pero no la impone; es decir, no existe obligación por parte de la comunidad autónoma de acordar la supresión de municipios por fusión o incorporación.

\section{Posibilidad de incorporación y de fusión en contra de la voluntad de los municipios. Resolución por Decreto o por Ley}

En todas las legislaciones autonómicas, como en la estatal supletoria, se prevé que los procedimientos de incorporación o fusión pueden comenzar de oficio por decisión de la Administración regional, y se puede llegar hasta el final de la incorporación o fusión en contra de la voluntad de los municipios afectados expresada en el trámite de audiencia o de los vecinos manifestada en el trámite de información pública que normalmente se requiere. En gran parte de las comunidades autónomas se mantiene la regla de que la decisión final compete al correspondiente Consejo de Gobierno, sin necesidad de ley, incluso aunque el procedimiento se haya iniciado de oficio y cuente con la oposición municipal (así, Murcia, Navarra, Aragón, Castilla-La Mancha, Castilla y León ${ }^{32}$ ). Pero hay comunidades autónomas que se apartan de esta regla y que en mayor o menor medida acogen la necesidad de intervención parlamentaria. Sus soluciones son de tres tipos:

- En el extremo opuesto, la Rioja exige en todo caso Ley de su Parlamento (art. 9.4 de su Ley de Administración Local), sea cual sea la alteración de que se trate y aunque se cuente con la voluntad conforme de los municipios afectados.

- Una solución intermedia es la de exigir Ley sólo en el caso de que haya oposición municipal; si no la hay, el Consejo de Gobierno puede resolver por Decreto, pero si la hay debe tramitar el procedimiento correspondiente y elaborar un Proyecto de Ley para su remisión al respectivo Parlamento regional. Así se prevé en Galicia, Asturias y Cataluña ${ }^{33}$.

- Singular es la regulación andaluza y madrileña: en todo caso la decisión es del Consejo de Gobierno mediante Decreto; pero, si hay oposición de los municipios, el Gobierno necesita el previo pronunciamiento favorable del Parlamento regional ${ }^{34}$.

\footnotetext{
32 Tampoco en el País Vasco es necesaria una ley de su Parlamento, pero aquí la competencia corresponde a las Diputaciones Forales, como ya se ha recordado antes.

33 Dice, por ejemplo, el 18.2 del TR de la Ley Municipal y de Régimen Local de Cataluña: «En caso de que el expediente haya sido iniciado de oficio ... o a instancia del consejo comarcal, la alteración de los términos tiene que aprobarse por ley del Parlamento, si en el trámite de informe formulan oposición uno, o más de uno, de los municipios afectados». En la misma línea, art. 38.4 de la Ley de Administración Local de Galicia y art. 16 de Ley de Demarcación Territorial de los Concejos del Principado de Asturias.

34 Ni siquiera es idéntica la solución en Madrid y en Andalucía. El art. 16.2 de la Ley de Administración Local de Madrid dice: «Si alguno de los Municipios afectados no aprobase la alteración de términos munici-
} 
Todo ello, además, sin perjuicio de que, como ya dije al comentar la legislación supletoria, quepa siempre, incluso aunque se pueda hacer por Decreto, acordar la fusión o la incorporación por ley autonómica. Pero, aunque se haga por ley, siempre hay que seguir antes un procedimiento con los trámites del art. 13.1 LRBRL y, especialmente, con audiencia a los municipios afectados.

Por lo demás, también admiten que el procedimiento se inicie a solicitud de los ayuntamientos, aunque esto, como hemos dicho, es casi ilusorio tratándose de la supresión. Y lo mismo puede decirse de la iniciativa vecinal, que parece más pensada para las segregaciones, aunque algunas normas la prevén sin circunscribirla a este caso. Además, en algunas comunidades, se prevé la iniciación a instancia de la diputación respectiva que, en otro caso, debe informar ${ }^{35}$.

\section{Sucesión de municipios; en especial, cambio en los órganos municipales}

Buena parte de las leyes autonómicas se ocupan de los efectos de las incorporaciones y fusiones, en cuanto a la sucesión del personal, bienes, deudas y órganos de gobierno. Pero no hay novedades dignas de mención respecto a la legislación estatal supletoria. En particular no las hay en lo que se refiere a la pérdida de la condición de alcalde y concejales de los municipios extintos: ninguna norma matiza o pospone la pérdida de la condición de alcalde o concejal.

\section{Previsión de figura de reorganización territorial de amplitud}

Algunas comunidades autónomas se han conformado con establecer expresamente que cabe en un mismo expediente varias reformas ${ }^{36}$. Pero lo que interesa destacar es que en algunas se han previsto operaciones de reorganización municipal de mayor alcance o amplitud. Es el caso, por ejemplo, de Aragón. El art. 17 de su Ley de Administración Local dispone:

\footnotetext{
pales, el Gobierno de la Comunidad de Madrid podrá aprobarla definitivamente previa audiencia de los Municipios interesados y dictamen del Consejo de Estado y autorización mediante Ley de la Asamblea de Madrid». Según el art. 17.2 de la Ley andaluza de Demarcación sólo se dice que, antes de aprobar el Decreto en el caso de la fusión (no de la incorporación), si se ha manifestado la voluntad contraria de algún municipio (por el pleno o por los vecinos), se requerirá la «aprobación previa y expresa del Parlamento andaluz». Pero no parece que esa aprobación adopte la forma de Ley. Mención especial merece la situación en el País Vasco donde la decisión corresponde a las Juntas generales. Vid. Rafael BARRANCO VELA, Creación y segregación de municipios, cit., pág. 284.

35 No es el caso, naturalmente, de las comunidades autónomas uniprovinciales. Tampoco el de Cataluña donde el informe de la diputación se sustituye por el del consejo comarcal.

36 Baste el ejemplo del art. 15 de la Ley Foral de Administración Local de Navarra que permite resolver al mismo tiempo fusión, incorporación alteración de términos.
} 
Art. 17. Programas de reorganización del territorio. 1. Cuando uno o varios municipios, debido a su despoblación, carezcan de base demográfica que posibilite su funcionamiento efectivo como organización jurídica de la respectiva colectividad, y la incorporación a otros o la fusión entre sí no pueda dar solución al desempeño de las competencias obligatorias y de los servicios mínimos por la propia situación objetiva de los municipios limítrofes, podrán plantear a la Diputación General de Aragón su integración en un plan de reorganización del territorio, que incluya las alteraciones del mapa municipal que se estimen precisas para la mejor gestión del territorio afectado. Esta iniciativa podrá partir también, de oficio, de la Diputación General de Aragón, previa audiencia de los municipios afectados...

3. Los programas de reorganización del territorio serán remitidos, antes de su ejecución, para conocimiento de las Cortes de Aragón. Las alteraciones del mapa municipal serán objeto de tramitación y resolución conjunta, con arreglo al procedimiento general regulado en la presente Ley... ${ }^{37}$.

Aunque se remite al Parlamento regional, la aprobación corresponde al Gobierno. Distinto es lo previsto en el Texto Refundido de la Ley Municipal y de Régimen Local de Cataluña:

\section{Art. 22. Reforma de la organización municipal}

22.1. Si las medidas de fomento... o la intervención de los entes supramunicipales no son suficientes para garantizar un nivel homogéneo en la prestación de los servicios de competencia municipal, el Gobierno puede iniciar un proceso de reforma de la organización municipal en los ámbitos territoriales de Cataluña que lo requieran...

22.3. La propuesta que adopte el Gobierno... tiene que enviarse como proyecto de ley al Parlamento de Cataluña.

22.4. La ley de reforma, en función de las características de los municipios afectados, tiene que determinar: a) Las técnicas de alteración de términos aplicables en cada caso.... ${ }^{38}$.

\section{Posibilidad de referéndum}

Incluso al margen de consideraciones jurídicas, el referéndum local parece especialmente adecuado para decisiones tan trascendentales como éstas que

37 En el art. 36 del Reglamento se establece como contenido de los programas «reforma de la estructura municipal mediante alteraciones de los términos municipales, que conlleven fusiones o incorporaciones de municipios para obtener como resultado municipios con territorio, población y riquezas suficientes». Es similar el art. 18 de la Ley de Administración Local de La Rioja.

38 Más dudoso es si los llamados «planes generales de viabilidad municipal» previstos en la disposición adicional segunda de la Ley de Castilla y León incluyen la posibilidad de supresión de municipios. Vid. José Luis MARTíneZ LóPEZ-MuÑIZ, «La Administración local en Castilla y León», Revista de Estudios de la Administración Local, n. 291 (2003), pág. 647. 
afectan a la misma existencia municipal ${ }^{39}$. Además, debe notarse que la CEAL cuando se ocupa en su art. 5 de la «protección de los límites territoriales de las entidades locales», no sólo impone que las colectividades locales afectadas sean consultadas previamente, sino que además añade que deben serlo «llegado el caso, por vía de referéndum allá donde la legislación lo permita». Y el Derecho español admite el «referéndum municipal» en el art. 71 LRBRL, pero con restricciones:

«De conformidad con la legislación del Estado y de la Comunidad Autónoma, cuando ésta tenga competencia estatutariamente atribuida para ello, los Alcalde, previo acuerdo por mayoría absoluta del Pleno y autorización del Gobierno de la Nación, podrán someter a consulta popular aquellos asuntos de la competencia propia municipal y de carácter local que sean de especial relevancia para los intereses de los vecinos».

La STS de 3 de mayo de 2004 (f. j. 5, Arz. 2559) entendió que no cabía convocar una consulta popular sobre una segregación de parte de un municipio para creación de otro porque «no se trata de asuntos de la competencia propia municipal, ya que no le compete la resolución final». Tal conclusión es discuti$b e^{40}$. Desde luego se trata de asuntos de «especial relevancia para los intereses de los vecinos»; y si bien es verdad que el precepto transcrito circunscribe esta figura a los asuntos de competencia municipal y carácter local y aunque todas las supresiones y creaciones de municipios no lo son - pues siempre decide la comunidad autónoma y siempre hay afectados intereses supralocales -, la consulta popular se puede conectar con la competencia del pleno para pronunciarse y con el interés local que, sin perjuicio de otros, existe indudablemente. La misma previsión del art. 5 CEAL podría justificar en parte una interpretación más flexible del art. 71 LRBRL. Pero, incluso aunque se aceptara la posibilidad de consultas populares sobre supresiones o creaciones de municipios, su resultado nunca sustituiría a las decisiones de los órganos ordinarios ni es vinculante para ellos ${ }^{41}$; o sea, que en nuestro caso se exigiría el pronunciamiento del pleno que, al menos jurídicamente, no estaría obligado a seguir la voluntad popular. Incluso en estas materias, su valor sería aun menor porque, como ya nos consta, ni siquiera el acuerdo del pleno tiene valor definitivo y ni siquiera la CEAL lo impone pues se conforma con que las entidades afectadas sean «consultadas». Así las cosas, el referéndum, caso de admitirse, sólo podría sus-

\footnotetext{
39 Así, dice Jean de SAVIGNY, ¿El Estado contra los municipios?, cit., pág. 250: «La cuestión de la supervivencia del municipio podría ... zanjarse por medio de un referéndum municipal (que) tendría el mérito de evitar a los representantes locales del municipio el planteamiento de un difícil caso de conciencia en el momento en que apareciese un problema de fusión; muchos consejeros municipales estiman con buena lógica que fueron elegidos para administrar el municipio y no para suprimirlo...».

40 Vid. Severiano FERNÁNDEZ RAMOS, Comentario al artículo 71, en en la obra dirigida por Manuel REBOLLO PUIG y coordinada por Manuel IZQUIERDO CARRASCO, Comentarios a la Ley Reguladora de las Bases del Régimen Local, cit., II, pág. 1816, que cita incluso la STSJ de Aragón de 25 de febrero de 2002 en su apoyo.

41 Severiano FERNÁNDEZ RAMOS, ibídem, II, pág. 1809 a 1811.
} 
tituir, si acaso, al trámite de información pública y ni eso está previsto expresamente en ninguna de las regulaciones autonómicas de la materia ${ }^{42}$. Añadamos a esto una dificultad adicional: en todo caso el ámbito territorial de la consulta ha de ser el de un municipio ${ }^{43}$, de modo que, si hay varios municipios afectados y se quiere consultar a todos ellos, habrá que convocar tantas consultas populares como municipios y, en el caso de las segregaciones, habría que consultar a todo el municipio existente en ese momento y no sólo a esa parte que aspira a la segregación ${ }^{44}$.

\section{Del fomento y otras formas de dulcificar las incorporaciones y fusiones; en particular, la reencarnación del municipio extinto en una entidad inframunicipal o en un órgano desconcentrado}

Como ya vimos, el apartado 3 del art. 13 LRBRL admite que el Estado establezca medias que tiendan a fomentar la fusión de municipios. Hasta esta competencia estatal, que era especialmente cuestionable y que efectivamente fue cuestionada por alguna comunidad autónoma, resultó salvada por la STC 214/1989. Pero es que, además, las leyes autonómicas establecen ellas mismas medidas de fomento de las fusiones y de las incorporaciones. Bastará reproducir un buen ejemplo como es el de la Ley de Régimen Local de Castilla y León:

Art. 18. Para el fomento de las fusiones e incorporaciones de municipios con población inferior a mil residentes, se establecen las siguientes medidas y beneficios que serán desarrolladas reglamentariamente:

1. Se creará un fondo o dotación destinado a acciones directas de fomento y a la concesión de ayudas para una mejor prestación de los servicios de los municipios resultantes.

2. $\quad$ Se fijarán preferencias en su favor y a los mismos fines en los regímenes generales de ayudas a municipios que apruebe la Junta de Castilla y León...

3. Para facilitar la integración y la eficaz prestación de los servicios municipales, las Diputaciones Provinciales prestarán a los municipios resultantes asistencia y asesoramiento adecuados y establecerán en su favor prioridades y preferencias en los Planes Provinciales de Cooperación.

\footnotetext{
42 Por ello quizás puede que ni siquiera sustituya al trámite de información pública sino que se le superponga. En ese sentido, Juan Ramón FERNÁNDEZ TORRES, La creación de nuevos municipios por segregación, Tirant lo blanch, Valencia, 2003, pág. 65.

43 Severiano FERnÁNDEZ RAMOS, Comentario al artículo 71, en la obra dirigida por Manuel REBOLLO PUIG y coordinada por Manuel IZQUIERdo CARRASCO, Comentarios a la Ley Reguladora de las Bases del Régimen Local, cit., II, págs. 1812-1813.

44 Sin embargo, Rafael BARRAnCo Vela, Creación y segregación de municipios, cit., pág. 220, mantiene la posibilidad de consultas populares para los vecinos de un núcleo de población.
} 
4. ${ }^{\circ}$ Se promoverán los convenios y acuerdos oportunos para una eficaz coordinación de las anteriores medidas de fomento con alas que pueda establecer el Estado... ${ }^{45}$.

Se ha dicho por algunos que estas medidas de fomento son inútiles. Y probablemente, en efecto, sea cierto que no sirvan para llevar a ningún municipio a optar voluntariamente por su extinción, aunque se le anuncie que pasará a mejor vida tras su muerte. Pero si no verdadero fomento de la fusión o incorporación voluntaria, sí que pueden ser medios adecuados para que se ofrezca menos resistencia a la desaparición forzosa, para hacer más llevadero el tránsito a la vida tras la muerte.

En esa misma dirección hay otras fórmulas que, aunque ya no merezcan de ninguna forma el nombre de fomento, pueden también tener un valor persuasivo. De un lado, la conversión del municipio extinto en una de esas «entidades de ámbito territorial inferior al municipio». De otro, posponer la efectividad de la supresión a un momento posterior.

La primera de estas fórmulas está acogida en nuestro Derecho. Ya la legislación estatal supletoria, tratando de hacer algo más dulce el amargo trago de la extinción como municipio, prevé que esos fusionados o incorporados a otros conserven esa modesta administración propia que es la entidad local menor. Así lo establece el art. 41 RPDT: «Los núcleos de población separados ... con características peculiares dentro de un municipio, podrán constituir entidades de ámbito territorial inferior al municipio: a) Cuando se suprima el municipio al que pertenecen...; c) Cuando por alteración de los términos municipales pasen dichos núcleos a formar parte de otros municipios...». Así, en definitiva, se consagra una cierta descentralización municipal que permitirá que el pequeño pueblo conserve alguna posibilidad de administración de sus propios asuntos. Las legislaciones autonómicas han explotado esta posibilidad. Algunas comunidades autónomas simplemente han previsto esta posibilidad de forma similar a la legislación estatal ${ }^{46}$. Pero en algún caso se va más lejos: se permite la tramitación simultánea de la supresión del municipio y de su constitución en entidad local menor, e incluso se le dispensa de alguno de los requisitos para tomar esta forma $^{47}$; o hasta se admite que se haga todo en un mismo expediente y una

45 De manera similar, pueden verse, entre otros, art. 13 de la Ley de Administración Local de Galicia, art. 20 del TR de la Ley Municipal y de Régimen Local de Cataluña; art. 16 de la ley de Aragón; art. 10 de la Ley castellano-manchega de Entidades Locales que para determinados casos establece que «la Comunidad Autónoma garantizará la inversión para el primer establecimiento de los servicios mínimos».

46 Así, art. 20 de la Ley de Entidades Locales Menores de Cantabria; art. 82.4 de la Ley de Administración Local de Madrid.

47 Así, art. 87 de la Ley de Administración Local de Aragón: «2. Para la creación de una nueva entidad local menor será necesario que el núcleo separado tenga una población mínima de 250 habitantes, salvo cuando se acuerde como consecuencia de la fusión o incorporación de municipios y ello facilite la permanencia de la titularidad y disfrute privativo de bienes destinados tradicionalmente a basar la subsistencia de una población determinada. 3. En estos casos los expedientes de fusión o incorporación de municipios y de la constitución de la entidad local menor podrán tramitarse simultáneamente». Otro ejemplo, en art. 19 de la Ley Navarra: «Los municipios que se extingan como consecuencia de los procesos de alteración de términos municipales 
única resolución ${ }^{48}$. La legislación catalana ofrece, junto a esta alternativa, otra más modesta: el municipio extinto puede pasar a ser una «entidad local descentralizada» (que es la denominación que allí se ha dado a las entidades inframunicipales) pero, además, cabe que pase simplemente a tener órganos específicos de participación ${ }^{49}$. O sea, que, en vez de una descentralización municipal, puede producirse sólo una desconcentración. Aunque otras leyes autonómicas no lo prevean, es una alternativa posible en todo caso.

La segunda fórmula a la que quiero referirme no está prevista. Consistiría en demorar la efectividad de la incorporación o fusión a un momento posterior a aquél en que se acuerde; posponerla, como mínimo, a las siguientes elecciones locales. Debe ser duro ganar unas elecciones y ser alcalde o concejal del propio municipio, y terminar el mandato, no ya sin ser alcalde o concejal, sino sin municipio. Además, se conseguiría evitar la engorrosa misión de nombrar comisiones gestoras y la difícil gestión de éstas, así como el déficit transitorio de representatividad que se genera en esa situación interina ${ }^{50}$. Nada se pierde, por el contrario, por mantener unos pocos años más una situación que lleva muchos y para un cambio que ha de durar muchísimos más.

El Prof. Parada afirma que estos municipios microscópicos se mantienen, entre otras cosas, porque dan posibilidades de poder, trabajo y sueldo a infinidad de militantes de los grandes partidos políticos ${ }^{51}$. Pues si esto fuera cierto, quizás la supresión de estos minimunicipios resulte más fácil si, al menos, se conserva una administración local inframunicipal en la que seguir ocupando un cargo y si, para colmo, el mal se retrasa algo. Y, ya al margen de estas modestas aspiraciones personales, que acaso no sean tan mezquinas, parece más que razonable que estos núcleos de población que vienen gozando de municipio, no se vean desposeídos de la noche a la mañana de toda administración propia y de toda expresión jurídi-

podrán quedar integrados en el municipio resultante con la condición de concejos, si su población de derecho excede de 15 habitantes que supongan, al menos, tres unidades familiares».

48 Sirve de muestra la Ley de Régimen Local de Castilla y León: según su art. 52 cabe crear una entidad local menor: «a) Cuando se suprima el municipio a que pertenezcan; b) Cuando por alteración de los términos municipales pasen dichos núcleos a formar parte de otros municipios...»; y, de acuerdo con su art. 56: «1. En el procedimiento de supresión de un municipio, su Ayuntamiento podrá solicitar ... que el núcleo quede constituido como entidad local menor. 2. La resolución que ponga fin al procedimiento de supresión así lo acordará ...».

49 En el Texto Refundido de la Ley Municipal y de Régimen Local, para unos casos sólo se prevé la constitución de los núcleos separados como órganos de participación (art. 20.2) mientras que en otros se admite esa posibilidad y también su constitución como entidades descentralizadas (art. 22.4). Pero en el Reglamento de Demarcación Territorial y Población, parece que siempre es posible cualquiera de las dos soluciones (art. 7.5).

50 No es ocioso traer aquí el hecho de que algún Tribunal alemán estimó una demanda contra una fusión de municipios por entender que había sido conculcada la autonomía «por la falta de una debida representación ciudadana (se trataba de un supuesto en el que después de la incorporación de un municipio a otro, los órganos municipales de éste no habín sido adecuadamente renovados). El Tribunal entiende que la representación de todos los ciudadanos exige que después de los cambios de las estructuras locales se proceda a nuevas elecciones». Vid. Francisco Sosa WAGNER y Pedro De Miguel García, Creación..., cit, pág. 123.

51 51J. Ramón PARADA VÁZQUEZ, La segunda descentralización..., cit., págs. 41-42. 
ca. Seguramente es bueno para el funcionamiento del municipio resultante y hasta para el sistema en su conjunto que no sea así. El logro completo de estos propósitos dependerá de que se configuren adecuadamente estas entidades inframunicipales, de que sirvan para dar satisfacción a las necesidades y aspiraciones de esos núcleos de población y no sean una inagotable fuente de problemas para la gestión municipal. A este respecto, creo que todavía es mucho lo que se puede avanzar, aunque algunas leyes autonómicas han dado pasos acertados.

Si bien distinta de las anteriores, tampoco parece mala idea para suavizar y preparar la desaparición de municipios lo previsto en el Reglamento aragonés de Territorio y Población de las Entidades Locales, esto es, la posibilidad de crear mancomunidades como paso previo para la definitiva fusión:

Art. 34. Asociación preparatoria de una futura fusión. 1. Los municipios que constituyan una mancomunidad para la prestación de una pluralidad de funciones o servicios podrán incluir en sus Estatutos previsiones que contemplen entre sus objetivos preparar una futura fusión de los municipios mancomunados, una vez transcurrido un periodo de colaboración en común.

2. Con tal fin, las inversiones en obras y servicios se programarán con una visión de conjunto que facilite esa fusión futura.

3. Podrán concederse ayudas complementarias motivadas por ese proyecto de fusión y condicionadas a que ésta se formalice en el plazo que se establezca, que no podrá exceder de cinco años.

\section{Referencia a la creación de municipios}

Como he dicho, no pretendo ocuparme directamente de la creación de municipios o segregación. Pero al menos conviene dejar reflejada alguna idea aunque sólo sea para situar en su contexto la supresión de municipios y ofrecer una visión algo más completa sobre las modificaciones del mapa municipal.

Si ya en la legislación de régimen local preconstitucional se trataba de contener la creación de nuevos municipios - legislación que en gran parte se ha incorporado al TRRL como Derecho supletorio- , se ha afirmado que el art. 13.2 LRBRL es más restrictivo que toda la legislación precedente ${ }^{52}$. Es discutible. Pero no lo es, desde luego, que la legislación autonómica reciente ha establecido criterios algo más severos que los de la legislación estatal supletoria ${ }^{53}$. Por ejem-

\footnotetext{
52 Francisco Sosa Wagner y Pedro de Miguel García, Creación, supresión y alteración de términos municipales, cit., pág. 69: «...el legislador básico ha establecido un criterio abiertamente más restrictivo para la creación de nuevas entidades municipales que el manejado por el legislador precedente...».

53 Vid. Rafael PiZArRo NeVAdo, Comentario al artículo 13, en la obra dirigida por Manuel ReBOLLO PUIG y coordinada por Manuel IZQUIERDO CARRASCO, Comentarios a la Ley Reguladora de las Bases del Régimen Local, cit., I, págs. 274 a 279.
} 
plo, si antes se requería que no comportara una disminución o un riesgo de diminución en la capacidad y calidad de los servicios públicos, ahora se llega a exigir, no ya que no se disminuya la calidad de los servicios, sino que incluso comporte positivamente una mejora en la prestación ${ }^{54}$. Y junto a ello se han establecido algunos requisitos mínimos objetivos para poder crear un municipio, mínimos que antes no existían. Desde luego no son ni remotamente tan rigurosos como los de la legislación portuguesa, con los que no resisten la comparación y sólo en algún caso imponen la población que generalmente se considera adecuada para una municipalidad racional ${ }^{55}$. Los extremos están entre la Rioja, que impone un mínimo de 500 habitantes y que el municipio del que procedan no baje de esa cifra, y Galicia donde se exige, de una parte, que tanto el municipio creado como el de procedencia queden con una población mínima de 5.000 habitantes, y, de otra, $10 \mathrm{~km}$ entre el núcleo segregado y la capitalidad del municipio anterior o, en algunos casos, sólo $5 \mathrm{Km}$ de suelo no urbanizable ${ }^{56}$.

Más allá de estas regulaciones abstractas, en su aplicación, en general, los poderes públicos no son propensos a crear nuevos municipios, ni siquiera ante lo que pudieran llegar a ser municipios sostenibles. Podrá afirmarse, quizás, que no se deduce de las leyes un criterio general opuesto a la creación de nuevos municipios cuando se dan los requisitos legales ${ }^{57}$. Pero, aun así, además de que esos

54 Art. 11.2 de la Ley de Régimen Local de Murcia; Art. 8.3. de la Ley andaluza de Demarcación Municipal.

55 Jean de SAVIGNY, ¿El Estado contra los municipios?, cit., págs. 242-243, la sitúa en el umbral de los 5.000 habitantes.

56 Soluciones intermedias hay en otras legislaciones autonómicas. Así, Andalucía, donde el nuevo municipio ha de contar al menos con 4.000 habitantes y una franja de suelo no urbanizable entre los núcleos principales de 7.500 metros; pero en algos casos, sobre todo si han sido durante cinco años entidad inframunicipal, bastan 2.500 habitantes y 5.000 metros. Otros ejemplos:

- Art. 15 de la Ley de Administración Local de Madrid: «Existencia de un núcleo de población de, al menos, 1.000 habitantes, territorialmente diferenciado con una distancia mínima de suelo no urbanizable o urbanizable no sectorizado de dos kilómetros».

- Art. 10 de la Ley de Régimen Local de Castilla y León: exige un mínimo de 1.000 residentes.

- Art. 15 del TR de la Ley Municipal y de Régimen Local de Cataluña: se exigen 2.000 habitantes para el nuevo y que no baje de esa cifra el municipio del que se segrega; además se requiere una franja de al menos 3.000 metros de suelo no urbanizable entre los núcleos más próximos de los municipios resultantes.

- Art. 16.4 de la Ley de Navarra: «No pueden crearse por segregación nuevos municipios si no cuentan con más de 1.000 habitantes de derecho».

- Art. 15 de la Ley de Castilla-La Mancha de Entidades Locales también exige 1000 habitantes pero con una excepción: «Las entidades de ámbito territorial inferior al municipio, constituidas cinco años antes de la entrada en vigor de esta Ley, podrán constituirse en municipio independiente cuando ...su población de derecho sea como mínimo de 500 habitantes y el municipio del que se segregan mantenga una población de derecho superior a los 10.000 habitantes, una vez producida la segregación».

- Art. 11.b) de la Ley de Administración Local de Aragón: «que el municipio de nueva creación cuente con una población mínima de 1.000 habitantes, sin que, como resultado de la segregación, el municipio o municipios de que procedan las porciones segregadas pase a tener una población inferior a esa cifra».

57 Así lo ha defendido Juan Ramón FERNÁNDEZ TORRES, La creación de nuevos municipios por segregación, Tirant lo blanch, Valencia, 2003, sobre todo págs. 21 y ss. 
requisitos se van haciendo más exigentes, su concurrencia no basta ${ }^{58}$ como tampoco basta la voluntad de la población ${ }^{59}$, población que no tiene un derecho a formar un municipio ${ }^{60}$ ni puede invocar en su favor la autonomía local ${ }^{61}$. Al final, hay una decisión con un último núcleo discrecional, por mucho que con acierto se acote y reduzca ${ }^{62}$; y esa discrecionalidad se utiliza con notable prevención frente a la aparición de nuevos municipios. Quienes han estudiado recientemente las segregaciones afirman que la incapacidad del Estado y de las comunidades autónomas para suprimir los municipios que no debieran subsistir se ha tratado de compensar absurda e injustamente restringiendo la creación de nuevos municipios incluso cuando está justificada. Y así sucede en gran medida: ya que no se entierra a lo moribundos, no se deja nacer a otros nuevos cuyas aspiraciones se consideran embarazosas y tratan de abortarse. Podría pensarse que pagan justos por pecadores y que, al final, se consigue desajustar aún más el mapa municipal pues no sólo subsisten municipios que no debieran seguir siéndolo sino que se impide el nacimiento de los que podrían y deberían serlo. También a este respecto se presenta como alternativa la constitución de una entidad inframunicipal ${ }^{63}$. Otras veces, la solución podría encontrarse en el traslado de capitalidad desde el núcleo de población tradicionalmente más importantes pero ahora decrépito al núcleo pujante y con pretensiones segregacionistas. Por una u otra vía, lo cierto es que, con independencia de lo que se deduzca de la lectura de las leyes, sólo con cuentagotas se aprueban segregaciones.

\section{LA DOCTRINA DOMINANTE SEGÚN LA CUAL LA AUTONOMÍA LOCAL NO IMPIDE NI LIMITA LA SUPRESIÓN DE MUNICIPIOS}

Pese a la proclamación constitucional de la autonomía local y, en concreto, de la municipal (art. $139 \mathrm{CE}$ ), no se ha cuestionado seriamente la constitucio-

\footnotetext{
58 STS de 22 de enero de 2001 (Ar. 1582): los requisitos legales «son sólo el presupuesto mínimo necesario e indispensable para (la creación) pero no significa que su existencia necesariamente conduzca a ello. La decisión final debe implicar un margen de discrecionalidad que permita valorar otros aspectos... que puestos en función del interés público prevalente justifiquen esa denegación».

59 Juan Ramón FERNÁNDEZ TORRES, La creación ..., pág. 34: «Resulta así innegable que la voluntad de la mayoría de los habitantes del núcleo que pretende segregarse no es una condición suficiente, aunque sea necesaria».

60 MuÑoz Machado, Tratado de Derecho Administrativo y Derecho público general, Iustel, Madrid, 2009, III, pág. 1037.

61 SSTS de 16 de enero de 1998 y 16 de mayo de 2001.

62 Rafael BARRANCO VELA, Creación y segregación de municipios, cit., págs. 169 y ss.

63 En algunas Leyes aparece expresamente como alternativa a la segregación la constitución de órganos desconcentrados o entidades locales menores; ej. art. 10.4 de la Ley de Administración Local de Aragón: «En aquellos casos en que la importancia de un núcleo de población o de sus actividades, sin reunir las condiciones necesarias para la creación de un nuevo municipio, hiciera conveniente una administración dotada de cierta autonomía, podrá instarse la creación de un órgano desconcentrado o de una entidad local menor...».
} 
nalidad de esta legislación ni, en particular, de su previsión de sistemas de supresión de municipios - por incorporación o por fusión - en contra de la voluntad de los municipios afectados. Sabiendo el exceso de municipios ínfimos y la racionalidad de su supresión, conociendo y hasta admirando las experiencias de Derecho comparado en la reestructuración de sus mapas municipales, parece poco menos que insensato afirmar que es contrario a la autonomía garantizada constitucionalmente la supresión de municipios. Además, la Carta Europea de la Autonomía Local se limita a este respecto a consagrar que «las colectividades locales afectadas deberán ser consultadas previamente», de donde se deduce que tampoco este texto opone reparos a la supresión forzosa una vez cumplido ese trámite formal.

Tan claro se ve esto, que el TC se lanzó a afirmarlo sin que nadie se lo cuestionara. Lo que se le planteaba era la creación de comarcas y cómo ello podía afectar a los municipios. Pero la STC 214/1989, en su fundamento 13.c), aprovechó para decir que ni «aun en el supuesto extremo de la supresión de municipios, la garantía institucional de la autonomía local constituye un obstáculo insalvable, por cuanto dicha garantía sólo se entiende a la existencia misma de esa autonomía y, por tanto, de las corporaciones gestoras de la misma, pero no, obviamente, al mantenimiento de un determinado statu quo organizativo»; es decir, «que la garantía institucional de la autonomía local no puede preservar al municipio individualmente sino que su alcance (es) estrictamente institucional...». La doctrina mayoritaria acoge la misma conclusión ${ }^{64}$. Acaso se puedan ver en esta tajante afirmación del TC y de los autores las insuficiencias de la garantía institucional y puramente objetiva de la autonomía local. Pero es que, incluso cuando se ha ensayado una garantía subjetiva, es decir una garantía de autonomía para cada municipio concreto con «derechos» a tener competencias, a autogobenarse, a contar con recursos económicos suficientes y a decidir sin interferencias, incluso entonces se dice que ese derecho no incluye el de la «propia supervivencia» y se proclama sin ambages «la inexistencia de un derecho constitucional de cada municipio a su existencia» 65 .

64 Es representativo Luciano PAREJo ALFOnso, Garantía institucional y autonomías locales, IEAL, Madrid, 1981, pág. 62: «... la garantía constitucional (de la autonomía local) no se opone a los fenómenos de supresión ... aun en contra de la voluntad de dichas corporaciones». Vid. también en el mismo sentido Antonio FANLo LoRAS, Fundamentos constitucionales de la autonomía local, Centro de Estudios Constitucionales, Madrid, 1990, pág. 265; Catalina ESCUín PALOP, «La alteración de términos municipales», cit., I, pág. 1272; y Antonio EMBID IRUJO, «Autonomía municipal», cit, págs. 452 y ss. La tesis contraria fue defendida por José Manuel CASTELLS ARTECHE, «Nueva problemática de las alteraciones territoriales municipales», Revista de Administración Pública, n. ${ }^{\circ}$ 100-103, vol. III, que en pág. 2178 afirma: «... la supresión de un determinado municipio ... impositivamente y sin contar con la libre voluntad de los municipios afectados parece que difícilmente podía resistir la contraposición con la garantía institucional...»; y así defiende «la necesidad de asegurar la supervivencia del municipio, si ésta es la voluntad de sus vecinos».

65 Francisco Velasco CABAllero, «Autonomía municipal», en La autonomía local. Administración y regulación económica. Títulos académicos y profesionales. Actas del II Congreso de la Asociación de Profesores de Derecho Administrativo, Thomson/Aranzadi, Cicur Menor (Navarra), 2007, pág. 56. 
La conclusión generalizada, por tanto, es rotunda y clara: se plantee como se plantee, incluso aunque se supere la garantía institucional y se intente construir una garantía subjetiva, nada impide la supresión de municipios en contra de su voluntad.

\section{NECESIDAD DE REPLANTEAR EL PROBLEMA Y LAS SOLUCIONES ANTE UNA SITUACIÓN CONSOLIDADA Y NO TAN TRÁGICA}

\section{Las posiciones menos favorables a cambios drásticos del mapa municipal consolidado}

Con lo expuesto hasta ahora, podemos dar por cumplida la misión que se me ha confiado. Pero no me resisto a ir algo más lejos. Porque, partiendo de las graves disfunciones que se atribuyen al minifundismo municipal, de los pocos o nulos obstáculos que alza la autonomía local a la supresión de municipios y de las facilidades que da la legislación vigente para abordarla, surge una pregunta inevitable ¿Por qué no se hace? ¿Por qué no lo hace ninguna de las diecisiete comunidades autónomas que tienen competencias para ello y ni siquiera aquéllas en las que el problema alcanza mayores cotas? Bien puede contestarse que eso sucede por desidia, por perversión, por corrupción, por cobardía de los políticos acomodaticios que quieren a toda costa evitar los conflictos que inexorablemente arrastran este tipo de medidas necesarias pero impopulares. Respuestas hay de ese tipo. Quizá haya algo de ello. No se descarta ninguna hipótesis. Pero me parece bastante más probable que la explicación pueda encontrarse mayoritariamente en otras razones. Dicho muy simplemente, pudiera ser que el problema no sea tan grave ni que su solución pase siempre e indefectiblemente por la supresión de municipios. Es más, tal vez sea ésta un remedio extremo cuando no haya otras alternativas más suaves que resulten suficientes. Pudiera ser que así lo imponga la autonomía local y, acaso, también la prudencia y la sensatez.

Sé el poco prestigio intelectual de que suelen gozar las posiciones eclécticas y moderadas. Sé que, ante la atomización municipal española, las vías suaves pueden ser vistas como soluciones de «paños calientes» que contemporizan con el problema sin arreglarlo. Sospecho incluso que en este foro luso-español, ante el envidiable ejemplo portugués de su muy racional mapa territorial y su comparación con el nuestro plagado de municipios raquíticos, aumentará la tendencia a optar por la solución radical de su supresión, incluso masiva. Sé que, por seguir con el símil ya utilizado antes, puede verse en las soluciones más moderadas una forma de seguir toreando el problema sin «coger al toro por los cuernos». Pero, pese a todos estos riesgos, conviene ofrecer el contrapunto a lo que hasta ahora se ha venido exponiendo. 
Si se tratara de establecer ex novo el mapa municipal español, probablemente lo mejor sería optar por una solución similar a la portuguesa. Pero no se trata de eso sino que hemos de partir de una situación muy distinta, consolidada jurídicamente y arraigada socialmente. Portugal, además de que nunca contó con una fragmentación municipal extrema, hizo tempranamente, en el momento oportuno, ese racional mapa municipal y seguramente ha hecho y hará muy bien en preservarlo. Por otra parte, acaso en Portugal no hayan dejado de plantearse algunos problemas con sus numerosas feligresías y sus reivindicaciones de mayor autonomía. No tengo datos bastantes pero me ha dado la impresión de que el problema que en Portugal se ha resuelto en el nivel municipal reaparece de forma no muy distinta en un nivel inferior. Sea como fuere, el que envidiemos esa organización portuguesa no es suficiente para concluir que debamos hacer lo mismo en España con casi dos siglos de retraso. Por lo menos, cabe dudar si lo que hubiera sido bueno antes de que los pequeños municipios se afianzaran lo es cuando llevan muchos años de vida y cuando nuestro ordenamiento y nuestra sociedad están articulados partiendo de su existencia. Tal vez aquí no se cumpla aquello de que «nunca es tarde si la dicha es buena».

Algunas voces se han oído en este sentido. Hace ya algún tiempo fue el Prof. Morell quien defendió profundizar en el establecimiento de una amplia diversidad capaz de adaptarse a las singularidades del pequeño municipio, «lo cual es muy distinto de la pura supresión - explicaba - como se propugna desde una visión estrictamente tecnocrática del problema» ${ }^{66}$. Después adoptaron una posición similar, entre otros, los Profs. Fanlo ${ }^{67}$ y Tornos ${ }^{68}$. Y finalmente este punto de vista ha encontrado reflejo en el «libro blanco para la reforma del gobierno local» de 2005 que, queriendo «hacer de la necesidad, virtud», no sólo renuncia a grandes reformas del mapa municipal sino que le busca aspectos positivos:

«... a pesar de las notorias dificultades que muchos municipios muestran para la prestación de los servicios mínimos, no es realista plantear la reducción del mapa municipal en aras de alcanzar dimensiones idealmente más eficaces, pues no ha habido en España verdaderos intentos de "racionalización" y "simplificación” del mapa municipal en el pasado reciente ni se vislumbra tampoco en el futuro inmediato.

\footnotetext{
66 Luis Morell OCAÑA, La Administración local, Tecnos, Madrid, 1984, pág. 71.

67 Antonio FANLO LORAS, Fundamentos constitucionales de la autonomía local, cit., pág. 266: «... la solución de este grave problema no puede consistir en suprimir municipios, inadecuados en la mayoría de los casos como prestadores de servicios públicos, puesto que con ellos suprimimos un ámbito privilegiado de democracia... La solución pasa por el fomento del asociacinismo municipal flexible...».

68 Joaquín TORNOS MAS, «Elementos para la reorganización territorial de Cataluña», Anuario del Gobierno Local, 1999-2000, pág. 180: «El municipio tiene como elemento esencial el ser ente de participación política. Este rasgo puede justificar su subsistencia, aun cuando carezca de medios suficientes para actuar como administración prestadora de servicios. Admitida la posible subsistencia de entes municipales con el único fin de garantizar la representación política de su colectividad, la organización y asignación competencial deberá tener en consideración la diversidad de entes municipales...». Vid. también Joaquín ToRNOS, Eliseo AJA, Tomás Font, Juan PERUlles y Enoch AlberTí, Informe sobre las autonomías, Madrid, 1988, págs. 100-101.
} 
En tanto que el municipio es el primer nivel de representación democrática en el territorio y teniendo en cuenta que España es un país extenso y relativamente poco poblado, debemos considerar positiva la existencia de ayuntamientos y de otras entidades locales, incluso en comunidades muy reducidas. Es decir, tampoco debemos perder de vista los aspectos ventajosos de la existencia de un elevado número de municipios; esa circunstancia aporta valores positivos de diversa naturaleza, y que van desde la existencia de más instituciones con representación democrática hasta la preservación del medio ambiente o del acervo histórico del medio rural».

No hay que llegar a tanto optimismo para, con más modestia y simple resignación, reconocer que es difícil proceder a estas alturas a una gran reforma territorial, que quizás ahora ya no sea conveniente, y que caben algunas alternativas con las que obtener algunas ventajas con el mínimo de inconvenientes.

Se me dirá, entonces, que otros Estados han afrontado esa reforma mucho después que Portugal y se invocará seguramente el precedente de Alemania que durante los años 60 y 70 de la pasada centuria acometió un proceso de supresión de pequeños municipios con resultados notables: se redujeron a una tercera parte sus algo más de 24.000 municipios. Es, en efecto, una referencia fundamental para nosotros. Pero digamos que, pese a todo, subsistieron unos 8.500 municipios en la RFA, lo que no es poco, ni tan diferente de España, porque, aunque con menos población, tenemos más territorio. Digamos, además, que, ahora, tras la reunificación, y dado que la RDA no vivió un proceso similar, Alemania tiene unos 16.000 municipios, lo que da una situación media similar a la española. Por otra parte, no en todos los Länder el resultado fue igual; por ejemplo, en Baviera, aun con una severa reducción, quedaron y quedan más de dos mil municipios y sólo Renania-Palatinado, con menos población, cuenta con $2.300^{69}$. Pero es que, además, según da cuenta Pielow, estas medidas de reducción masiva de municipios «han recibido, hasta hoy, fuertes críticas por la pérdida de sustancia democrática y por el alejamiento del ciudadano como resultado de las creadas nueva áreas de la Administración local» ${ }^{70}$. Así que lo que fue un proceso complicado y conflictivo - hubo muchas tensiones y numerosos recursos contra estas medidas - no se juzga ahora como enteramente satisfactorio. Si Alemania es una referencia, debe serlo no sólo por lo que hizo con

69 Véase el informe «Estructura y funcionamiento de la democracia local y regional: Alemania, Austria, Países Bajos y Polonia» preparado bajo la autoridad del Comité director de las autoridades locales y regionales del Consejo de Europa y publicado en Anuario del Gobierno Local, 1996, págs. 735 y ss.; en concreto, sobre el número de los municipios de los diferentes Länder alemanes, pp 741 a 743 . También JohannChristian PIELOW, «Las estructuras del gobierno local en un marco federal: la asimetría y las singularidades», Anuario del Gobierno Local, 1999/2000, pág. 106; José Luis CARRo FERNÁNDEZ-VALMAYOR, «El régimen local alemán. Una introducción general», Anuario del Gobierno Local, 2005, pág. 238; Francisco Sosa Wagner y Pedro de Miguel García, Creación, supresión y alteración de términos municipales, págs. 105 y ss.

70 Johann-Christian PIELOW, «Las estructuras del gobierno local en un marco federal: la asimetría y las singularidades», cit., pág. 108. Sobre esos mismos «efectos negativos» comprobados a posteriori, Luciano PAREJo Alfonso, «La autonomía local en la Constitución», en Santiago MuÑOZ MACHAdo (Dir.), Tratado de Derecho municipal, Civitas, Madrid, 2. ${ }^{\text {a }}$ ed., 2003, I, pág. 105. 
los pequeños municipios sino también por la valoración que con el tiempo se da allí a aquella reforma. Tampoco en Austria la situación es muy distinta pues tiene 2.300 municipios, de los cuales más de 2.000 no llegan a los 5.000 habitantes $^{71}$. Y, puestos ya a mirar las experiencias de otros países, no está de más poner nuestros ojos en Francia con sus 36.500 municipios, de los cuales 32.000 tienen menos de 2.000 habitantes. Ni siquiera Napoleón, que se lo propuso, consiguió reducir mucho la cifra. Así no es de extrañar que los franceses hayan renunciado a esa aspiración y se contenten con reforzar la cooperación intermunicipal, incluso obligatoria ${ }^{72}$. En Italia, con 8.100 municipios, es decir, un número casi idéntico al de España, aunque con más población pero con menos territorio, tampoco se ha procedido a su reducción y en la actualidad se opta, más que por ello, por potenciar el asociacionismo de los pequeños municipios y por tratar de establecer un régimen adecuado a su menor capacidad económica y de gestión ${ }^{73}$.

Por otra parte, hay que aclarar que España no ha permanecido completamente ajena al proceso de reducción de municipios. Frente a la incontinencia del primer periodo del siglo XIX, ya la Ley de Organización y Atribuciones de los Ayuntamientos de 1845, no sólo contuvo el proceso de creación, sino que originó una drástica supresión de municipios ya existentes, casi dos mil, en poco más de diez años ${ }^{74}$. Ya mucho después, entre 1966 y 1976, como consecuencia de la Ley 48/1966, de 23 de julio, hubo otra notabilísima disminución de 1.025 municipios $^{75}$. Por tanto, algo se ha hecho ¿Hay que hacer mucho más?

71 Véase el informe «Estructura y funcionamiento de la democracia local y regional: Alemania, Austria, Países Bajos y Polonia» preparado bajo la autoridad del Comité director de las autoridades locales y regionales del Consejo de Europa y publicado en Anuario del Gobierno Local, 1996, págs. 735 y ss.; en concreto, sobre el número y población de los municipios austríacos pág. 775.

72 Jean-Louis AUTIN, «La reforma de la cooperación intermunicipal en Europa. Balance de la experiencia francesa», Anuario del Gobierno Local, 2003, págs. 241 y ss.; y Luciano VANDELLI, El poder local: su origen en la Francia revolucionaria y su futuro en la Europa de las regiones, traducción al castellano de Pablo MENÉndeZ García y José SuAY RinCón, MAP, Madrid, 1992, págs. 180 a 182.

73 Vid. Luciano VAndelli, Trastornos de las instituciones políticas, trad. Española de Tomás Cano Campos, Trotta y Fundación Alfonso Martín Escudero, Madrid, 2007, págs. 150 y ss.

$74 \mathrm{Su}$ art. 70 disponía que «se conservarán todos los ayuntamientos que hoy existen en poblaciones de más de 30 vecinos ... los de menor vecindario se agregarán a otros, o formarán, reuniéndose entre sí, nuevos Ayuntamientos». Téngase en cuenta que vecinos no eran todos los habitantes sino los cabeza de familia. El art. 71 autorizaba al Gobierno «para formar nuevos Ayuntamientos, oyendo a la Diputación provincial, en distritos que lleguen a 100 vecinos» siendo necesaria una ley para los de menor vecindario. Pero lo importante no es tanto el texto de la Ley, sino su aplicación efectiva. Según Enrique ORDUÑA REBOLLO, «Nuevas aportaciones sobre el mapa municipal español», cit., págs. 810 a 815, de los 11.271 municipios de 1842 se pasó a 9.355 en 1857. Así, en esa década moderada «se produjo la mayor disminución del número de municipios en toda la historia del municipalismo constitucional español, incluida la caída de 1970. En los quince años que median entre uno y otro censo desaparecieron 1916 ayuntamientos...».

75 Vid. Rafael Barranco Vela, Creación y segregación de municipios, Marcial Pons, Madrid, 1993, págs. 95 a 100; Francisco Sosa WaGNER y Pedro de Miguel GARcía, Creación, supresión y alteración de términos municipales, cit., págs. 54-55; Rafael PIZARRo NEVADO, Comentario al artículo 13, en la obra dirigida por Manuel Rebollo PUIG y coordinada por Manuel IZQUIERDo CARRASCO, Comentarios a la Ley Regula- 


\section{Los problemas de los pequeños municipios y los problemas derivados de otros factores}

Para contestar es oportuno hacer algunas observaciones a fin de no imputar a los pequeños municipios más desgracias de las que realmente causen. Centremos el problema que acaso tenga un alcance menos dramático del que pudiera parecer a primera vista.

En primer lugar, no hay que confundir el problema de los municipios ínfimos con una general insuficiencia del nivel municipal para muchas actividades que antes sí encontraban en él la escala perfecta. No echemos la culpa a los micromunicipios de los problemas del municipalismo en general. Por diversas causas, cada vez es más frecuente que allí donde otrora sólo se veían intereses locales ahora se detecten intereses supralocales o que, incluso al margen de eso, la economía de escala, ante las grandes inversiones y capacidad técnica que necesitan los servicios públicos en la actualidad, haga que el escalón municipal haya devenido insuficiente para lo que antes sí era adecuado. En este contexto, los pequeños municipios no son el problema; si acaso se ve en ellos más claramente un problema que afecta a todos los municipios.

Tampoco está de más reparar en que parte de las dificultades para conseguir servicios públicos de calidad no están en la existencia de municipios pequeños sino en la existencia de pueblos pequeños y alejados de otros. Pero esos pequeños y aislados pueblos existen y no debemos añadir al pliego de cargos contra la atomización municipal la parte de la dificultad para prestar servicios de calidad que más bien hay que imputar a la previa realidad geográfica y sociológica de dispersión de la población. Por las mismas razones ne se sabe bien qué se gana negando a esos pequeños pueblos hasta la existencia de una Administración municipal propia e integrándolos con otros pueblos en un único municipio ( $¿$ «Al que no tiene, aun lo que tiene se le quitará»?)

Por otra parte, las dificultades que suscitan los pequeños municipios son algo menores si, como sucede en España, ni las autoridades municipales son al mismo tiempo autoridades de otra Administración superior ni el término municipal es una circunscripción para ningún servicio estatal o autonómico. Además, en este caso hay menos legitimación estatal o autonómica para aniquilar a esos pequeños municipios cuando de ninguna forma condicionan la organización de los servicios estatales o autonómicos. El que se reconozca a un pueblo

dora de las Bases del Régimen Local, Tirant lo blanch, Valencia, 2007, I, pág. 284, nota 27. También con anterioridad hubo un proceso anexionista de pequeños municipios próximos por las grandes ciudades en los años 40 del anterior siglo que afectó sobre todo a Madrid; vid. Tomás Ramón FERNÁNDEZ RoDRíGUEZ, »Áreas metropolitanas y descentralización», en Sebastián MARTín-RETORTILlO (Dir.), Descentralización administrativa y organización política», Alfaguara, Madrid, 1973, tomo III, págs. 652 y ss. En nota 11 describe la anexión por Madrid de los pueblos próximos que hoy son simples barrios, como Chamartín, Carabanchel Alto y Bajo, Fuencarral, Vallecas, etc. 
como municipio no comporta que vaya a existir una escuela ni un centro de salud ni una modesta oficina de correos o una estación de autobuses. Los vecinos de ese pueblo, aunque sea municipio, tendrán que ir a la escuela o al instituto de otro pueblo; y, a la inversa, el cartero deberá de llevar allí las cartas o deberá parar allí algún autobús aunque no sea municipio. En Portugal, por ejemplo, el término municipal condiciona incluso al partido judicial, lo que de ninguna forma sucede en España, donde los partidos judiciales se extienden normalmente por varios municipios. Si acaso, en los municipios que no tengan otro órgano judicial, existirá un humilde juzgado de paz que hasta puede compartir con otros la oficina judicial (art. 99 Ley Orgánica del Poder Judicial).

En cuarto lugar, tampoco se debe achacar a los pequeños municipios los peligros de una autonomía local excesiva. Las exageraciones sobre la autonomía local son un error en sí mismas, aunque los municipios no sean pequeños, y hasta podría pensarse que sus riesgos aumentan en proporción al tamaño del municipio. Por ello, la primera medida profiláctica, no ya para contener los males del minimunicipalismo sino para que el municipalismo en general sea saludable, es concebir la autonomía local con moderación ${ }^{76}$. Lo que sí es verdad es que para los defensores a ultranza de una autonomía local extrema estos pequeños municipios resultan un estorbo insoportable. Así cuando se dice que los municipios no son Administraciones sino mucho más; cuando se ve en los Plenos algo así como un Parlamento y no un órgano administrativo, aunque representativo e importante; cuando se quiere equiparar sus normas a las leyes para que cubran incluso las reservas constitucionales de ley; cuando se asimila su sistema de organización al parlamentarismo o al presidencialismo como si en su seno hubiera algo similar a la división de poderes; cuando se pretende que deben tener la inmensa mayoría de las competencias; cuando paralelamente se quiere restringir al mínimo del mínimo los controles de otras Administraciones; etc. Cuando se opta por todo ello y esa especie de omnipotencia municipal, entonces bajar a la realidad de nuestros numerosos y diminutos municipios provoca un shock en el que, entre espasmos, se condena a esos enanos al exterminio como aguafiestas de la orgía municipalista. Pero en todo ello, además del error de base de una autonomía local desorbitada y desbocada, subyace un planteamiento desenfocado: se parte de lo que es la autonomía municipal y, en consecuencia, de lo que debe ser y hacer un municipio - conceptos estos, los de municipio y autonomía, que para estas teorías son previos y están en los cielos del mundo de las ideas; después se afirma que cualquier pueblo que no sea ca-

\footnotetext{
76 Pese a que otra cosa pudiera parecer a la vista de ciertas declaraciones y exposiciones doctrinales, se han dado algunos pasos en esta dirección muy acertados. Además de que la LRBRL tiene enormes virtudes y virtualidades, junto con algunas carencias y defectos, en distintos sectores se observan tendencias que moderan dentro de límites razonables la autonomía municipal. Es el caso, destacadamente del urbanismo donde por la vía de reconocer intereses supralocales y competencias conexas (sobre todo, de ordenación del territorio) se está produciendo un ajuste en el que la autonomía municipal, sin perder fuerza en su ámbito propio, se ve limitada razonablemente. No es ocasión de desarrollar esto. Suficiente es apuntarlo para desdramatizar la situación, aunque sea también reconociendo que todavía hay que avanzar en esa línea y que, en algunos aspectos, se ha caminado en la dirección opuesta.
} 
paz de hacer eso no debe ser un municipio. Pero es una forma de razonar un poco rara. Por lo menos aceptemos que hay otra forma de plantear la cuestión: se puede partir de que los pueblos, auténtica unidad social de convivencia básica, han de tener una Administración, que es la municipal; y, partiendo de esos pueblos reales, de sus necesidades y de sus posibilidades de autoadministración, se configura a su medida a los municipios y a su autonomía. Porque imagino, parafraseando la afirmación evangélica, que no se hicieron los municipios para la autonomía sino la autonomía para los municipios. Y aun antes cabría decir que no se hicieron los pueblos para los municipios sino los municipios para los pueblos, y todo ello para las personas. Se ha sacralizado al municipio y a su autonomía, y después se sacrifica en holocausto ante su altar a los pueblos incapaces de soportar el papel estelar que se ha decidido que representen. Pero quizá habría que pensar al revés. Es como si hiciéramos un traje grande y fastuoso para todos, critiquemos la existencia de personas menuditas y rústicas a las que les quede mal y los condenemos a la desnudez o a compartirlo con otros hasta conseguir que rellenen esa indumentaria. Lo que hay que hacer es distintos trajes y ayudar a todos - a los que son municipios y, aunque pequeños, merecen seguir siéndolo - a llevarlos con dignidad. De eso hablaremos de inmediato. Ahora basta concluir que los problemas que generan los pequeños municipios no son tan graves si no se incurre en excesos sobre la autonomía local. Lo que sí es seguro es que ellos no son responsables de tales errores y que la primera medida para atenuar las dificultades que suscitan bien puede ser construir un concepto más moderado y más maleable de autonomía. Es más, hasta podría suceder que estos pequeños municipios sean un buen antídoto frente a las exageraciones autonomistas.

\section{REPLANTEAMIENTO JURÍDICO: LÍMITES A LA SUPRESIÓN DE MUNICIPIOS}

\section{La autonomía sí se ve afectada por la supresión y, aunque no la impide, pone límites a las decisiones de fusión e incorporación}

No deja de resultar curioso que las tesis más rabiosamente autonomistas sean las que más tiendan a aceptar que la supresión de pequeños municipios no encuentra ningún límite en la autonomía. Se da a los municipios, podríamos decir, todos los derechos, menos el derecho a vivir; todos los derechos pero con aborto y eutanasia libre, aunque sean en este caso abortos y eutanasias municipales. Sin embargo, esa conclusión dominante, que antes expusimos, no me parece satisfactoria. Y tampoco aparece por ninguna parte el razonamiento que conduce a ella. Da la impresión de que se concluye eso intuitivamente, sólo para no negar una posibilidad que se ve lógica y que se ha aceptado en todas partes. Pero sin ese razonamiento se pierden algunos datos importantes y faltan respuestas a preguntas capitales. Porque, entonces, ¿tampoco sería contrario a 
la autonomía local $-y$, por ende, no sería inconstitucional- el que se suprimiera un municipio mediano, con población y riqueza suficiente para prestar dignamente los servicios públicos? ¿tampoco sería contrario a la autonomía una supresión municipal sin que se dieran los presupuestos de hecho descritos en las normas a que nos hemos referido? Si ello se hace por Decreto, el problema se solventará pues tal Decreto será contrario a la legalidad y podrá ser anulado por la jurisdicción contencioso-administrativa. Pero ya sabemos que en algunas comunidades autónomas la supresión debe acordarse por ley y en otras puede acordarse por ley ¿Nunca la supresión de un concreto municipio que acuerde una ley ad hoc será contraria a la autonomía local? Ahora ya no basta con decir que deben cumplir las previsiones genéricas de las leyes de régimen local: la LRBRL no impone nada más que límites formales a las comunidades autónomas en cuanto a las supresiones de municipios; y no parece que haya medios para imponer a la ley autonómica que acuerda una concreta supresión de un municipio determinado que respete la legislación autonómica general ${ }^{77}$, salvo que se vea en ésta una auténtica garantía de la autonomía local consagrada por la Constitución. Y, aun así, antes que ello, ¿pueden las leyes generales habilitar ampliamente a supresiones por fusión o incorporación de cualesquiera municipios aunque gocen de buena salud? Si se mantiene que la autonomía no da derecho a la existencia, a la supervivencia municipal, que la autonomía no tiene nada que ver con todo esto, habrá que responder que todas esas leyes, aunque supriman municipios saludables y hasta pujantes, son perfectamente constitucionales. Y eso me parece difícilmente aceptable y, en cualquier caso, nada convincente ni conveniente.

Yo creo que el planteamiento debe ser otro, que debe partirse de que, en efecto, la supresión de municipios sí que afecta a la autonomía, que la autonomía sí que confiere un «derecho» a la subsistencia de una comunidad local como municipio, como se acepta incluso en Francia ${ }^{78}$. Ahora bien, como en tantos casos en que se dice que no hay derechos absolutos, tampoco esta faceta de la autonomía municipal es absoluta: puede sufrir restricciones y excepciones. De una parte, hay casos en que realmente ya no existe la colectividad territorial como realidad social capaz de dar sustento a un municipio (así, cuando se

\footnotetext{
77 Aunque se aceptara que las leyes que suprimen un municipio concreto deben respetar la legislación autonómica general sobre supresión de municipios, si se considera que ello no afecta a la autonomía local no sé qué vía podría seguirse para conseguir su anulación. Tendría que conseguirse llegar al TC - sin poder usar el conflicto en defensa de la autonomía local puesto que se parte de que no está en juego la autonomía - y admitir luego que el TC controle la adecuación de una ley autonómica a otra ley autonómica, lo cual es casi acrobático. Con una pirueta no menor, podría combatirse esa ley que suprimiera un municipio solvente por considerarla una arbitrariedad de los poderes públicos prohibida por el art. 9.3 CE. Pero el sólo enunciado de esta vía da una idea de su dificultad.

78 Me parece un dato significativo el que en Francia, prototipo de Estado centralista en el que la autonomía local tiene un menor desarrollo, se ha afirmado tradicionalmente el derecho de los municipios a subsistir. Como explica Jean de SAVIGNY, ¿El Estado contra los municipios?, cit., págs. 229 y 237, pese a que el Derecho positivo no lo imponía, se entendió que para realizar fusiones era necesario «el acuerdo unánime de los respectivos Consejos municipales» y ello porque «habría un derecho de las personas morales a preservar su existencia, principio o derecho análogo al que tienen las personas físicas a ser defendidas en su integridad».
} 
confunden físicamente dos núcleos de población que hasta entonces constituían municipios diferentes o cuando un municipio queda tan mermado en su población que ya no forma realmente un grupo social completo). De otra parte, puede haber casos en que, al margen de lo anterior, el interés general exija la incorporación o la fusión de municipios. En estos casos, no es que no se afecte a la autonomía, sino que se considerará constitucional esa restricción a la autonomía siempre que quede acreditado que el interés público requiere inexcusablemente esa supresión de municipios y que la medida sea proporcionada de modo que no haya otras fórmulas para satisfacer el interés general menos restrictivas de la autonomía. Es esto mismo lo que me parece deducir de la jurisprudencia alemana de los Tribunales Constitucionales de los Länder que sintetizan Sosa y De Miguel ${ }^{79}$. Y es, además, lo único lógico pues resulta un despropósito afirmar que la autonomía local confiere amplios «derechos» a los municipios, pero no derecho a la vida. También es como mínimo extraño que se considere parte de la autonomía el derecho a ser oídos en los procedimientos correspondientes para la extinción y se mantenga al mismo tiempo que la autonomía no tiene nada que ver con la subsistencia como municipio.

En cualquier caso, quede claro que lo que aquí se defiende no lleva de ninguna forma a poner en cuestión la constitucionalidad de la legislación expuesta ni, en especial, la supresión de municipios en contra de su voluntad. Pero sí comporta ciertos límites en su aplicación y una garantía de que la potestad de supresión no se utilizará innecesaria o desproporcionadamente; menos aún arbitrariamente.

Hay, por otra parte, quizás, otro límite al legislador que engarza con el significado más profundo del municipio. Vértigo y miedo siento de adentrarme en

\footnotetext{
79 Francisco Sosa Wagner y Pedro De Miguel García, Creación..., cit, págs. 117 y ss. Explican allí, por ejemplo, que el Tribunal Constitucional de Rheinland-Pfalz, por vulneración de la garantía de la autonomía y aplicando simultáneamente el principio de proporcionalidad, declaró inconstitucionales una serie de medidas cuyos objetivos pudieron conseguirse por medios menos contundentes que la supresión. También es ilustrativa su referencia a la jurisprudencia del Tribunal Constitucional de Baden-Württenberg: éste reconoce que en la supresión de municipios está en juego su autonomía pero sitúa al mismo nivel que ésta otros principio, como el del Estado social que exige una ordenación territorial que permita la prestación eficaz de los servicios, así como la eficiencia y ahorro, el de democracia que igualmente requiere municipios eficaces y que puedan hacer de contrapoder frente a la Administración del Estado. Por eso, analizando caso por caso, puede justificarse la restricción a la autonomía local. Pero, incluso así, el Tribunal afirma la «prohibición de cometer excesos» y con ello entra a controlar si la medida es o no adecuada para el fin que se persigue, la relación coste-beneficio y hasta «si el legislador ha elegido, de entre los medios disponibles, aquel que suponía una intervención menor en la garantía de la autonomía local». Según el Tribunal de Nordrhein-Westfalen la supresión de municipios afecta a la autonomía local de modo que «el derecho del Estado a alterar los términos municipales no puede considerarse ilimitado» pues «el legislador debe tomar en consideración la tradición y la vida propia de las corporaciones afectadas», de forma que «un municipio sólo puede ser suprimido por razones de interés público». Por ello el Tribunal se reconoce la facultad de «enjuiciar ... las circunstancias determinantes que se encuentran en la base de la decisión del legislador...». «Puede asimismo el Tribunal controlar o conocer si la ley impugnada resulta el medio más apropiado para conseguir el fin que el legislador se propone y si tal medio es proporcional... Ello permite, pues, controlar si las medidas adoptadas resultan excesivas en comparación con otras alternativas... Y en dos ocasiones se declaró la inconstitucionalidad de sendas leyes por infracción, justamente, de este principio de proporcionalidad...».
} 
él pues exige mucho más detenimiento del que aquí es posible y del que está a mi alcance. Pero al menos debe quedar apuntado. Un municipio, creo, no puede ser normalmente la forma jurídica y de administración de un territorio con diversos pueblos o ciudades, de un conjunto de personas que no son vecinos entre sí, que no tienen una convivencia cotidiana ni unos intereses comunes derivados de ella. Iba a decir que no puede ser eso sin desnaturalizarse. Pero rectifico y digo más modestamente que no puede ser eso conforme a nuestro concepto tradicional y arraigado de municipio, conforme a la concepción social y jurídica asentada entre nosotros de lo que es un municipio ${ }^{80}$. No puede ser el municipio una fórmula organizativa totalmente artificial determinada por la agrupación de pueblos en función de lo que aconseje la eficacia y la eficiencia administrativa. Que el municipio no puede convertirse en eso se vislumbra en la STC 214/1989 que, en el mismo fundamento 13.c) antes citado, dice : «la institución municipal ... aun en la hipótesis extrema no podrá diluirse para pasar a identificarse con la comarca. La configuración constitucional de la comarca como agrupación de municipios (art. 152.3 CE) impide, en efecto, la materialización del supuesto último del "municipio-comarca"». Esto mismo y de forma más concreta y acabada se deja sentir en la jurisprudencia y doctrina alemanas que de nuevo recogemos siguiendo a Sosa y De Miguel. Se establece que el territorio municipal no debe ser de tal forma excesivo que rompa la vinculación local o vinculación vecinal de sus habitantes. Cierto que también se quiere que los municipios tengan suficiente capacidad para ejercer sus competencias. Pero esto último no se puede conseguir a costa de que desaparezca por completo esa vinculación al lugar o vinculación vecinal ${ }^{81}$. O sea, no puede lograrse a base de crear municipios grandes o medianos eficaces y eficientes pero totalmente artificiales porque no sean la expresión jurídica de la realidad social de una colectividad local, de una comunidad basada en relaciones de vecindad. Creo que aquí se puede y debe detectar otro límite constitucional a las fusiones e incorporaciones muni-

80 Quizá esto no sea del todo ajeno a la garantía institucional de la autonomía municipal pues, según la STC 32/1981, ésta comporta la «preservación de la institución en términos recognoscibles para la imagen que de la misma tiene la conciencia social en cada tiempo y lugar» de modo que «la única interdicción claramente discernible es la de la ruptura clara y neta con esa imagen comúnmente aceptada de la institución». Aunque el TC no ha aplicado esta idea a la relación entre municipio y colectividad local basada en relaciones de vecindad, no me parece que sea imposible hacerlo. Como explicaba Adolfo PoSADA, Evolución legislativa del régimen local español, Librería de Victoriano Suárez, Madrid, 1910, con reedición del IEAL, Madrid, 1982, de donde se cita, págs. 37- 38, para los constituyentes de Cádiz «el sujeto de la vida municipal es ... el pueblo, o sea, el grupo de familias que habita en un espacio definido y que viven en relación de vecindad». Y desde entonces esa idea es la que late en todas las legislaciones sobre organización municipal cuya referencia es siempre el pueblo como grupo de familias que vive en relación de vecindad en un espacio determinado.

81 Francisco Sosa Wagner y Pedro De Miguel García, Creación..., cit, págs. 130 a 132. Explican que Seibert ha ido algo más lejos que la jurisprudencia dando una total prioridad a la vinculación local respecto a la capacidad de prestación de servicios. Pero sin llegar a ese extremo, sí que parece aceptarse comúnmente que hay que «compatibilizar el Estado democrático ... con la garantía ... de la autonomía» y que no es conforme con la Constitución conseguir la eficacia en prestación de servicios rompiendo la «vinculación local»: «... las medidas destinadas a perfeccionar la capacidad de prestación no deben conducir a una aniquilación de la vinculación vecinal que exige en este sentido una comunidad local». 
cipales, a las reestructuraciones del mapa municipal, un límite borroso y difuso, pero límite a fin de cuentas.

Se podrá argüir en contra de lo aquí sostenido que la Constitución garantiza la autonomía de los municipios, no de los pueblos, como sí decían muchos textos decimonónicos; que se garantiza la autonomía del ente jurídico, no de la realidad social de la colectividad local; que lo mismo ocurre en la Carta Europea de la Autonomía Local; y que basta que no exista municipio para que no haya ente al que atribuir la autonomía ni, por tanto, ningún límite a la fusión derivado de la autonomía. Pero me parecen argumentos demasiado formalistas: si no se quiere convertir la autonomía local en una pura entelequia hay que atribuirla a una colectividad local vecinal, no a cualquier cosa que el legislador decida llamar municipio ${ }^{82}$. Además, si los municipios llegasen a ser personificaciones jurídicas que no fueran la expresión de una comunidad local, se arruinarían casi todas las cualidades que se atribuyen a estas Administraciones locales, casi todas las razones que se invocan para justificar la autonomía local y para convertirla en una pieza esencial del sistema.

También se podrá argumentar en contra que lo que sostengo supone recuperar la idea revolucionaria de un ayuntamiento en cada pueblo o el no menos trasnochado municipalismo romántico que veía algo natural y consustancial en los pueblos y su expresión municipal, que la ley simplemente tenía que reconocer. Peor aún, porque, al menos en España, nunca se llevó hasta sus últimas consecuencias la idea de que todo pueblo tuviera un ayuntamiento sino algo más modesto; y porque entre nosotros siempre ha habido municipios que han agrupado a entes menores y, en cualquier caso, a numerosos núcleos de población ${ }^{83}$. Si esto se me opone, contestaré que no se trata de llevar las ideas al extremo de considerar que cualquier núcleo de población es un pueblo; y que no invoco estas ideas ni para justificar la creación de nuevos municipios ni para mantener los

82 Me parecen particularmente acertadas y agudas las observaciones de Luis MORELL OCAÑA, La Administración local, cit., págs. 17 a 24. Expone y critica que el primer carácter de la autonomía local en el Derecho público contemporáneo es que se atribuye a una entidad, el municipio; «no se considera, pues, como un atributo de la propia colectividad local sino de sui expresión institucional... Se ha consumado, así, una confusión sencillamente dramática ...». Y las consecuencias más negativas de ello las sitúa justamente en la supresión de municipios: «... la referencia de la autonomía al ente, y no a la colectividad, no puede ser objeto de ... admisión pacífica ... cuando se hace presente el tema de la reorganización en profundidad del Régimen local (...) Y es que, al imputar la autonomía al ente, y no a la colectividad social, se ha dejado al margen del ámbito de la autonomía local la cuestión de mayor trascendencia para la propia colectividad: la decisión sobre su existencia jurídica. La doctrina alemana de la garantía institucional silencia este problema, considerando heterónoma esta decisión... Ante semejante consecuencia, vale la pena romper el cerco que la propia evolución ha ido tendiendo a las autonomías locales, enlazándolas de modo directo con la propia colectividad...».

83 Además de lo que ya hemos dicho sobre la existencia de cerca de 4.000 entidades de ámbito territorial inferior al municipio, que testimonia suficientemente que el municipio ha jugado como ente intermedio en zonas rurales, además de eso, hay infinidad de municipios y en algunas regiones de España que son, en realidad, la suma de numerosos núcleos de población. El caso extremo es el Galicia donde, según cálculos de 1960, cada municipio tenía una media de más de 100 núcleos de población. Vid. Luis Morell OcAÑA, La Administración local, cit., pág. 62. 
existentes a ultranza sino sólo para que sea un factor que haya que considerar, para poner un freno a la supresión de municipios más allá de lo necesario.

En definitiva, se puede sostener que ni siquiera la conveniencia de una prestación eficaz y eficiente de los servicios públicos constituye un interés público suficiente de por sí para llegar a fusiones o incorporaciones que rompan por completo con toda vinculación local o vecinal. Como mínimo, me parece necesario afirmar que esas decisiones de fusión e incorporación no pueden prescindir completamente de una valoración de este factor de la vinculación vecinal que sólo se podría sacrificar cuando lo exija inexcusablemente un interés público prevalente.

Por esta vía, si no se llegan a detectar nuevos límites constitucionales a las posibilidades de supresión de municipios, sí que se refuerzan los ya antes enunciados de la necesidad y de la proporcionalidad, de suerte que sólo será lícita ante la insuficiencia de otras medidas alternativas menos lesivas de la autonomía de la colectividad local. Ello, claro está, sin perjuicio de que además será lícita cuando la supresión del municipio se base en la desaparición de una realidad social a la que propiamente pueda considerarse un pueblo.

\section{Control de la supresión de municipios para garantizar la autonomía local}

Lo que vengo defendiendo en este epígrafe permite un control jurisdiccional de las fusiones e incorporaciones, incluso aunque la supresión municipal se haya adoptado por ley singular. No sólo un control de los requisitos formales del art. 13.1 LRBRL, que no ofrece particulares problemas. Sino también un control de fondo, de la existencia de un interés público prevalente, de los hechos determinantes invocados para la supresión y un control de la proporcionalidad. Incluso cabrá que se controle que las leyes singulares de supresión de un concreto municipio respeten las previsiones de las leyes generales sobre incorporación o fusión. No se tratará realmente, aunque lo parezca, de controlar que una ley singular respeta una ley general sino de controlar que la ley singular no vulnera la autonomía local y para ello jugará como criterio, con mayor o menor valor, la ley general. En nuestro Derecho, actualmente, es un cauce adecuado el del conflicto en defensa de la autonomía local que regulan los arts. 75 bis y siguientes de la Ley Orgánica del Tribunal Constitucional ${ }^{84}$. Naturalmente, si la supresión se hace por Decreto la impugnación ante la jurisdicción contenciosoadministrativa no plantea dificultad alguna y, además, el control de cumplimiento de legalidad y de proporcionalidad podrá ser pleno.

\footnotetext{
84 Recuérdese que da legitimación para plantear este conflicto ante el TC al municipio que sea destinatario único de la ley impugnada o a un número de municipios que sea al menos de un séptimo de los existentes en el ámbito territorial de aplicación de la ley. Es difícil que un municipio fusionado o incorporado por ley no reúna, incluso individualmente, estos requisitos.
} 


\section{ALTERNATIVAS A LA SUPRESIÓN DE MUNICIPIOS}

Si antes (epígrafe I.3) ya anunciábamos la conveniencia de analizar alternativas a la supresión de municipios, ahora, tras lo que acabamos de razonar sobre la autonomía local, se comprende que no es sólo una cuestión de oportunidad sino hasta una necesidad jurídica. Si la supresión forzosa sólo está justificada cuando es necesaria, cuando no es una limitación desproporcionada y excesiva, entonces hay que indagar las posibles alternativas para ofrecer el marco en el que las fusiones e incorporaciones serán lícitas.

\section{Régimen especial de organización y funcionamiento adecuado a los pequeños municipios}

Como remedios específicos para el minimunicipalismo, hay que prever diferenciaciones de régimen jurídico para encontrar una vestidura que, siendo municipal, sea adecuada a los pequeños pueblos, a sus posibilidades pero también a sus necesidades y aspiraciones ${ }^{85}$. La obra del siglo XIX, en España como en Francia y en otros Estados, no fue sólo la de la instauración de municipios en pequeñas aldeas y en grandes ciudades sino la de establecer para todos ellos un régimen sustancialmente uniforme pues en esa uniformidad se veía, no sin razón, una forma de racionalizar y simplificar el abigarrado y confuso panorama del Antiguo Régimen y de garantizar la igualdad de los ciudadanos. Ahora, la alternativa a suprimir los pequeños municipios pasa en primer lugar por romper esa uniformidad, aun reconociendo los muchos servicios que ha prestado y sus ventajas. La idea no es nueva sino que, aunque entonces minoritaria, está casi en los mismos orígenes de esa uniformidad monolítica. Lo expresó maravillosamente Vivien: «Una ley uniforme coloca al legislador en una rígida alternativa: restringir los derechos de todos a causa de las incapacidades de algunos, lo que es una injusticia, o atribuir derechos que algunos son incapaces de utilizar, lo que puede comprometer los intereses generales; y dado que estos últimos deben en cualquier caso prevalecer, una organización uniforme conduce al inevitable resultado de hacer imposible la emancipación de la Administración local» ${ }^{86}$. Las diferencias podrían $-\mathrm{y}$ hasta deberían - afectar a muy diversos aspectos, incluso al grado de control o tutela y al estatuto de los representantes locales ${ }^{87}$. Pero nos ceñiremos aquí a aquellas diferenciaciones que encuentran más fácil acomodo en la legislación básica vigente.

\footnotetext{
85 En general, criticando la uniformidad pese a las diferencias de población y reclamando una mayor diversidad, Luis ORTEGA ÁLVAREZ, «Diferenciación frente a uniformidad en la organización territorial local», cit., págs. 78 y ss.

86 Citado por Luciano VANDELLI, El poder local..., pág. 35, nota 31. La frase aparece en en el comentario de Vivien a la Ley Municipal de 1837 en Jurisprudence Générale ou repertoire alphabetique Dalloz, voz «commune», pág. 252.

87 Vid. Jean de SAVIGNY, ¿El Estado contra los municipios?, cit., págs. 92 a 94.
} 
Hay ya algunas especialidades orgánicas en la misma legislación básica estatal: muchos municipios pequeños, y obligatoriamente todos los de menos de 100 habitantes, funcionan en régimen de concejo abierto (art. 29 LRBRL), por tanto, sin ni siquiera ayuntamiento, sino con una asamblea vecinal presidida por un alcalde ${ }^{88}$; en otros, los de menos de 5.000 habitantes, no es obligada la existencia de junta de gobierno local ni de las comisiones informativas (art. 20 LRBRL); además de que la existencia de un régimen específico para los municipios de gran población (que ha resultado finalmente que no son tan grandes) marca también una diferencia notable con los pequeños.

Pero también se adapta y simplifica el régimen jurídico de estos pequeños municipios. Una muestra bien significativa de ello ofrece la Ley de Haciendas Locales. Su art. 148.5 prevé una notable simplificación para la estructura de los presupuestos de los municipios de menos de 5.000 habitantes; y su art. 184.2, dispone un «tratamiento contable simplificado» para aquellas entidades locales «cuyas características así lo requieran y que serán fijadas reglamentariamente por el Ministerio de Economía y Hacienda», que lo ha establecido para los municipios de menos de 5.000 habitantes $^{89}$.

En esta dirección se puede y se debe avanzar mucho. Y en buena parte lo han hecho varias comunidades autónomas de acuerdo con lo autorizado por el art. 30 LRBRL que remite a las leyes autonómicas el establecimiento de «regímenes especiales para municipios pequeños o de carácter rural» ${ }^{90}$. Ilustrativa es la Ley de Administración Local de Aragón. Más que el régimen especial para municipios de menos de 1.000 habitantes (art. 58), interesa destacar el previsto para «municipios con núcleos de población diferenciados» (art. 60) que, aunque en la Ley aparece sin perfilarse mínimamente, ofrece una idea original y sugerente capaz de dar solución a la peculiaridades de munchos municipios y «evitar tendencias segregacionistas» ${ }^{91}$. También merece ser citada la previsión de la legislación castellanoleonesa respecto a lo que pueden considerarse «municipios cabecera», esto es, aquellos que cuentan con servicios (culturales, educativos, sanita-

88 Vid. Luis CosCulluela MonTANER, «El concejo abierto», Revista de Estudios de la Administración Local y Autonómica, n. ${ }^{\circ} 234$ (1987); y Rafael PizARro Nevado, Comentario al artículo 29, en en la obra dirigida por Manuel Rebollo PUIG y coordinada por Manuel IZQUIERDO CARRASCO, Comentarios a la Ley Reguladora de las Bases del Régimen Local, Tirant lo blanch, Valencia, 2007, I, págs. 755 a 771.

89 Orden de 17 de julio de 1990 por la que se aprueba la Instrucción de Contabilidad de tratamiento especial simplificado para entidades locales con población inferior a 5.000 habitantes.

90 La Ley de Administración Local de Madrid, por ejemplo, prevé que mediante Ley se establezca «un régimen de organización y funcionamiento simplificado para municipios con población inferior a 1.000 habitantes» y, al margen de esto, la elaboración de «modelos-tipo de actas, ordenanzas y cualquier documento municipal». Así mismo, art. 77 de la Ley de Régimen Local de Castilla y León, para municipios de menos de 5.000 habitantes, que son la inmensa mayoría de los de esa comunidad autónoma, de modo que, más que un régimen especial, puede ser, de hecho, el régimen común. Especial interés presenta el régimen especial para municipios de menos de 5.000 habitantes de Navarra, al que luego nos referiremos.

91 Vid. Ramón Salanove AlCALDE, «La organización territorial de Aragón», en Antonio EMBID IRUJO (Dir.), Derecho público aragonés, Zaragoza, 4. ${ }^{\mathrm{a}}$ ed., 2008, págs. 359-360. 
rios, etc.) que satisfacen las demandas de los vecinos de los municipios limítrofes y para los que se prevé un trato preferencial por la comunidad autónoma ${ }^{92}$

En cualquier caso, más allá de estas previsiones legales, como quiera que las leyes sólo establecen la organización necesaria quedando la complementaria en manos de los propios municipios, es un hecho que, salvo raras excepciones, los pequeños municipios cuentan con una organización mínima y poco costosa, a veces muy original ${ }^{93}$.

\section{La adaptación de las competencias a las posibilidades y necesidades de los pequeños municipios}

Más allá de la reducción orgánica y de la simplificación de régimen jurídico, también puede y debe haber diversidad en cuanto a las competencias municipales y aceptar que los pequeños municipios tengan menos que los medianos y grandes ${ }^{94}$; o, sobre todo, ejerzan menos competencias o asuman menos responsabilidades que estos otros; o, dicho desde otra perspectiva, que en ellos ejerzan más competencias y asuman más responsabilidades las otras Administraciones públicas. No hay nada novedoso en ello y sólo se trata, si acaso, de ahondar en esa dirección. Al igual que ya se hacía antes, el art. 26 LRBRL establece más o menos servicios mínimos obligatorios para los municipios en función de su mayor o menor población y justamente un salto notable se sitúa en los 5.000 habitantes: los de menos sólo han de garantizar alumbrado público, cementerio, recogida de residuos, limpieza viaria, abastecimiento domiciliario de agua potable, alcantarillado, acceso a núcleos de población, pavimentación de las vías públicas y control de alimentos y bebidas. A partir de ese umbral de los 5.000 habitantes empiezan a aumentar los servicios municipales mínimos.

Pero la diversidad de competencias puede ser mucho mayor y hasta establecerse de manera relativamente informal para adaptarse a cada sector y a cada

\footnotetext{
92 Sobre esta figura y las dudas que suscita, vid. José Luis MARTínEZ LóPEZ-MuÑIZ, «La Administración local en Castilla y León», cit., pág. 645.

93 Por ejemplo, hay municipios que gestionan su servicio de cementerio o hasta de mantenimiento del alumbrado público con un modo tan original y seguramente económico como el arrendamiento de servicios. Vid. A. LeKUONa ZABALA, «La gestión de los servicios públicos locales: el alumbrado público y el cementerio en los municipios guipuzcoanos», Revista Vasca de Administración Pública, n. ${ }^{\circ}$ 56. No sé si habrá estudios que lo desmientan, pero quizá ni siquiera sea cierto que los pequeños municipios, aun incluidas las retribuciones de sus alcaldes y concejales, sean poco eficientes en el gasto en comparación con los mayores, pues pudiera suceder que la burocracia municipal aumente en progresión geométrica cuando la población aumenta en progresión aritmética.

94 La idea luce expresamente en el nuevo Estatuto de Autonomía de Cataluña. En su art. 84, dedicado a las competencias municipales, su apartado 3 dice que «la distribución de las responsabilidades administrativas ... entre las distintas administraciones locales debe tener en cuenta su capacidad de gestión ... y se rige ... por el principio de diferenciación , de acuerdo con las características que presenta la realidad municipal...». La misma idea se reitera en el art. 88 que consagra lo que denomina el «principio de diferenciación» y que afecta no sólo al régimen orgánico, funcional y financiero sino también específicamente al competencial.
} 
realidad municipal. Hay infinidad de ejemplos y modalidades en nuestra legislación, algunos ya con bastantes años. Pueden consistir en una atribución alternativa o indistinta o concurrente de competencias a los municipios y a otra Administración ${ }^{95}$. La Ley de Tráfico y Seguridad Vial, por ejemplo, atribuye la competencia sancionadora respecto a las infracciones cometidas en las vías urbanas a los alcaldes; pero de seguido añade que los delegados o subdelegados del Gobierno «asumirán esa competencia cuando por razones justificadas o por insuficiencia de los servicios municipales, no pueda ser ejercida por los alcaldes» (art. 68.2). Otro ejemplo notable, entre innumerables de ellos, ofrece la ya referida Ley gallega de Administración Local que, además, lo presenta como una aplicación del principio de subsidiariedad ${ }^{96}$. Después de establecer los servicios públicos que obligatoriamente deben prestar los municipio, dispone: «Si el establecimiento o prestación de los servicios (obligatorios) resultase imposible o de muy difícil cumplimiento, en aplicación del principio de subsidiariedad, los municipios podrán solicitar de la Junta de Galicia la dispensa de la obligación de prestarlos». Si se accede a esta dispensa, la resolución que la acuerde deberá decidir «el órgano o la Administración que deberá asumir el servicio» y las aportaciones económicas municipales que procedan para sufragarlo total o parcialmente. Con unas u otras variante, hay otras muestras similares de la misma idea en muy diversas leyes sectoriales. Es ilustrativo el caso

95 Sobre estas formas de atribución de competencias en general, vid. Rafael ENTRENA CUESTA, Curso de Derecho Administrativo, volumen I/2, Organización administrativa, Tecnos, Madrid, 10. a ed., 1994, págs. 68-69; y Luis Cosculluela Montaner, Manual de Derecho Administrativo, Thomson/Civitas, Madrid, 18. a ed., 2008, págs. 174-175. Su terminología no coincide exactamente. Pero no será necesario aquí hacer mayores precisiones, pues los ejemplos que ahora se expondrán son suficientemente ilustrativos de los fenómenos a que nos referimos.

96 No creo que se trate de una invocación errónea del principio de subsidiariedad territorial. Éste puede aplicarse de dos formas diferentes. Normalmente el principio de subsidiariedad se refiere a la atribución legal de las competencias y supone un mandato al legislador para que atribuya preferentemente las competencias a las Administraciones locales. Pero también puede verse una proyección de la misma idea en una técnica de sustitución en el ejercicio de las competencias: el Estado o la Región ejercerá una determinada competencia nada más que en la medida en la que la Administración local - que será la titular de la competencia y la primeramente llamada a ejercerla - no lo haga. Aquí, el criterio de que los objetivos de la acción pretendida no puedan ser alcanzados de manera suficiente por las Administraciones locales y, por tanto, tales objetivos puedan lograrse mejor en el nivel estatal o regional» se aplica a posteriori, una vez comprobada, ante una entidad local específica, la insuficiencia de este escalón administrativo más cercano y mostradas con toda evidencia las necesidades que justifican la actuación de una Administración superior. Esta facultad de sustitución facilita, incluso, la atribución legal de competencias a las entidades locales que ya no se hará con riesgo grave de que la incapacidad de gestión o financiera de los municipios menores dañe a los intereses generales. Estas sustituciones están próximas, por una parte, a los mecanismos de colaboración y, por otra, a la sustitución por incumplimiento de las obligaciones locales que prevé el art. 60 LRBRL. Pero son más que una forma intensa de colaboración y se diferencian, por otra parte, de las sustituciones basadas directamente en el artículo 60 LRBRL porque para éste el presupuesto de hecho no es fundamentalmente la incapacidad o insuficiencia de la entidad local, sino más bien un incumplimiento voluntario de sus obligaciones. Sobre todo ello, vid. Manuel REBOLLo PUIG y Mariano LóPEZ BENíTEZ, en el informe sobre España, en la obra colectiva dirigida por Robert ANDERSEN y Diane DÉON, Droit Administratif et subsidiarité, Bruylant, Bruselas, págs. 82 y 104 a 107. En la misma línea, Vid. José Luis MARTíNEZ LóPEZ-MuÑIZ, «Cooperación y subsidiariedad intermunicipal», cit., pág. 67: «... donde existan colectividades locales de esas (pequeñas) dimensiones... la subsidiariedad exigirá el reconocimiento y la atribución a la autoridad que en ella exista o se establezca de las competencias que lógicamente respondan a su potencial humano y económico ...». 
de la Ley de Madrid de Protección de los Consumidores de 1998. Dos de sus artículos serán suficientes para dejar constancia:

\section{Artículo. 62. Competencias de la Comunidad Autónoma. ...}

2. Corresponde a los órganos autonómicos competentes en materia de protección al consumidor... en particular, al menos, las siguientes actuaciones:... actuar supletoriamente en aquellos municipios que no puedan desarrollar las funciones previstas en la presente Ley.

Art. 63. Competencias de las entidades locales.

1. (Las enumera)

2. Las competencias contempladas en el apartado anterior serán asumidas directamente por los órganos competentes en materia de protección al consumidor y de la salud de la Comunidad de Madrid, a fin de mantener el equilibrio regional y cuando sea aconsejable una actuación integral y siempre que concurran algunas de las siguientes circunstancias:

a) Carencias de medios de las entidades locales...97

Al margen de estas específicas previsiones legales sectoriales, el sistema se desarrolla frecuentemente conforme a estas pautas que encajan perfectamente en el marco diseñado por la LRBRL. Recuérdese que admite que la autonomía local no se traduzca siempre en competencias municipales exclusivas sino en el derecho de los municipios a intervenir en los asuntos que afecten directamente al círculo de sus intereses (art. 2) y que ello puede adoptar la simple forma de participación en procedimientos cuya resolución corresponda a la Administración estatal o autonómica (art. 62); que así mismo impone que se atribuyan auténticas competencias «en atención ... a la capacidad de gestión de la entidad local» (art. 2) y que eso permite y aun obliga a diversificar el haz de competencias según el tamaño de los municipios. De otra parte, su art. 28 permite a los municipios realizar actividades complementarias de las de otras Administraciones en materias tan importantes como educación, sanidad o vivienda, cultura, promoción de la mujer o protección del medio ambiente, actividades complementarias que pueden ser extensas en grandes municipios y nulas en los peque-

97 En este mismo ámbito de la protección de los consumidores, otras comunidades autónomas han ideado diversas fórmulas igualmente expeditivas y simples para conciliar la atribución de competencias a los municipios con el reconocimiento de competencias de la Administración regional que suplirá sin problemas ni formalidades la insuficiencia de la acción municipal, sobre todo la de los pequeños municipios. Así, la Ley andaluza 13/2003 de Defensa de los Consumidores, confiere a todos los municipios amplísimas competencias de inspección y sanción, pero ello siempre sin perjuicio de que también tiene competencia la Junta de Andalucía. Se completa esa idea con el deber de los ayuntamientos de comunicar a la Junta la organización de sus servicios de inspección y los medios personales y materiales con que cuenten, así como un acuerdo plenario sobre su propósito de ejercitar las competencias. Es un sistema de competencias indistintas en el que late el propósito de adaptarse a la situación, capacidad y aspiraciones de cada municipio, de modo que en función de ello la Administración regional asumirá directamente más o menos responsabilidades. 
ños. Incluso el simple desenvolvimiento natural y espontáneo de unos y otros municipios hará que sus actividades sean más o menos vastas. Porque los municipios, de conformidad con la cláusula general de competencias (art. 25.1 LRBRL) y con su facultad para el ejercicio de la iniciativa pública económica (art. 86 LRBRL), pueden tener, en realidad, muy diverso ámbito de actuación, según sus necesidades y aspiraciones, necesidades y aspiraciones que con toda lógica dependerán en gran medida del tamaño de la población. Incluso en lo que se refiere a su intervención en la actividad de los ciudadanos (art. 84 LRBRL), la acción municipal será de muy distinta amplitud y contenidos en unos y otros municipios, también, entre otras cosas, en función del tamaño, por la sencilla razón de que en los pequeños ámbitos de convivencia pueden no ser ni remotamente necesarias detalladas ordenanzas sobre ruidos o contaminación atmosférica o edificación o telecomunicaciones, etc. Quiere decirse con todo esto, no sólo que es lícito y conveniente, sino hasta frecuente, que las leyes establezcan un diverso ámbito de competencias según el tamaño de los municipios; que además puede hacerse con mecanismos simples que se amolden fácilmente a las diferentes realidades municipales; y que, incluso sin ello, nuestro sistema jurídico permite y propicia que la actividad municipal sea de muy distinta amplitud y contenido, acomodándose naturalmente a las menores necesidades de los pequeños municipios.

\section{La cooperación con los pequeños municipios de las demás Administraciones, en particular de las provincias}

La subsistencia de los pequeños municipios requiere de otra parte intensificar las relaciones administrativas. Sobre todo las de colaboración y cooperación ${ }^{98}$; pero también las de coordinación. La necesidad de esta última no es tanto consecuencia de la existencia de pequeños municipios como, con independencia del tamaño, de su elevado número y de la fragmentación del territorio que comporta. Pero aun así conviene tener presente que nuestro Derecho apodera ampliamente a las Administraciones superiores para coordinar la actuación de los municipios de modo que por esta vía se admiten, en el fondo, las restricciones más destacables de la autonomía local. Conste, al menos, que los arts. 10.2 y 59 LRBRL autorizan la coordinación forzosa de las Administraciones locales entre sí y con las restantes Administraciones cuando sus actividades

\footnotetext{
98 Existe cierta confusión en España sobre estos dos términos que unas veces se manejan como sinónimos y otras como alusivos a conceptos diferentes; y, aun cuando se diferencian, a lo que algunos autores llaman colaboración otros denominan cooperación y viceversa. Siguiendo lo que parece mayoritario en la legislación y en la doctrina, hablaremos aquí de colaboración para referirnos a los casos en que varias Administraciones trabajan conjuntamente o se ayudan para cumplir cada una sus objetivos y permaneciendo todas ellas en el ámbito de sus competencias. Por el contrario, con el término de cooperación nos referiremos a los supuestos en que una Administración ayuda a otras para que éstas cumplan los objetivos que les son propios. Así, cooperación es sinónimo de asistencia o auxilio administrativo. No obstante, la frontera es borrosa. Vid. Manuel Rebollo PUig, «Los consorcios entre entes locales como forma de cooperación.», Anuario del Gobierno Local, 1997, págs. 224-225.
} 
trasciendan el interés local y condicionen o sean concurrentes con los supralocales. Ello, a veces, puede ser, junto con otras fórmulas, una alternativa a la supresión de municipios en tanto que sea suficiente para garantizar el interés público supralocal y, como es una medida menos restrictiva que la supresión, también es una medida preferente. Pero debemos centrarnos en la cooperación con los pequeños municipios y en la colaboración entre ellos mismos.

Tanto la Administración del Estado como la de las comunidades autónomas desarrollan una amplia labor de cooperación con los municipios, especialmente con los de menos capacidad económica y de gestión, para que puedan ejercer adecuadamente sus competencias y, en especial, prestar los servicios públicos obligatorios. Es ésa una constante en la legislación de régimen local ${ }^{99}$ que también aparece en muchas leyes sectoriales para la concreta actividad administrativa de que se ocupan. Pero, además de ello, hay instrumentos más específicos a los que conviene pasar revista para ofrecer el panorama general en el que se encuentran los pequeños municipios y las fórmulas para superar o atenuar sus carencias.

Por lo pronto, de acuerdo con la LRBRL, la misión más esencial de la entidad local provincial es «garantizar los principios de solidaridad y equilibrio intermunicipales»y, en particular, «asegurar la prestación integral y adecuada en la totalidad del territorio provincial de los servicios de competencias municipal» (art. 31). O sea, cooperar con los municipios, ayudarles, auxiliarles ${ }^{100}$.

Consecuentemente con ello se atribuye a las diputaciones o a las otras corporaciones provinciales, no ya sólo la «coordinación de los servicios municipales entre sí», sino muy específicamente «la asistencia y la cooperación jurídica, económica y técnica a los municipios, especialmente los de menor capacidad económica y de gestión» (arts. 36 y 38). Esto se refiere sobre todo a los pequeños municipios y, con mayor o menor concreción, eso es lo que establecen las leyes autonómicas ${ }^{101}$. En el fondo, acaba siendo muy parecida la competencia que atribuye a las diputaciones el art. 36.1.c) respecto a «la prestación de los

99 Incluso ha pasado a integrarse en algunos Estatutos de Autonomía; así, art. 26.4 del nuevo Estatuto de Castilla y León.

100 Son interesantes las observaciones de Manuel ZAFRA VíctoR, «Reflexiones sobre el gobierno local», Anuario del Gobierno Local, 2004, págs. 102 a 106, sobre la relevancia de las Diputaciones basándose en las necesidades de los pequeños municipios. También, muy especialmente para nuestro objetivo, es ilustrativo de esta tendencia lo que afirma Luciano PAREJo AlFonso, «La autonomía local en la Constitución», en Santiago MuÑoz MAChADo (Dir.), Tratado de Derecho municipal, cit., I, pág. 105, que explica que en España se ha renunciado «a toda reforma territorial» y se aceptan «las insuficiencias gestoras» de los pequeños municipios, pero al mismo tiempo se pretende «resolver estas últimas mediante la traslación del deber de su corrección o superación al escalón local superior (provincial)...».

101 Por ejemplo, en Andalucía, su Ley 11/1987 especifica que la cooperación y asistencia de las diputaciones debe beneficiar «preferentemente a los municipios con población inferior a 20.000 habitantes» (arts. 6 y 10). 
servicios públicos de carácter supramunicipal y, en su caso, supracomarcal» ${ }^{102}$ : esta competencia de las diputaciones respecto a los servicios supramunicipales no es nada más que una forma singular e intensa de cooperación que puede llegar a la sustitución de los municipios, de forma que, a la postre, acaba pareciéndose a lo que antes hemos visto sobre la atribución indistinta o concurrente de competencias a los municipios y a otra Administración. Hasta tal extremo es la cooperación con los municipios, especialmente con los pequeños, la función esencial de las diputaciones que se la presenta como su signo de identidad y su única justificación y misión ${ }^{103}$. No es eso lo que aquí se defiende. Nos basta enfatizar que la intensa y extensa cooperación de las entidades provinciales es un instrumento sobresaliente para aliviar las insuficiencias de los pequeños municipios y que su reforzamiento es también un instrumento alternativo que ha de tomarse en consideración a la hora de evaluar los males del pequeño municipio y de decidir o no su supresión.

Sin entrar aquí en detalle en las competencias de las islas ni de las comarcas, señalemos al menos que también tienen por misión capital la de cooperar con los municipios en la prestación de servicios ${ }^{104}$. Es más, en algún caso sus atribuciones son en esencia las mismas de las diputaciones aunque con un ámbito territorial más reducido. Concretamente en Cataluña, donde abundan los micromunicipios, la comarca aparece claramente marcada por ese carácter.

102 Sirve para atestiguarlo la misma Ley andaluza 11/1987. Se comprueba en ella (arts. 15 a 18) que, en realidad, no se trata exactamente de unos servicios de competencia propiamente provincial para la gestión de los intereses peculiares de la provincia, sino de servicios de competencia municipal que, por tanto, afectan a los intereses municipales y que, no obstante, se desarrollan en un ámbito superior al del término municipal que, desde luego, no tiene que ser el de toda la provincia. Así, se dice que, «a los efectos de esta Ley, se consideran servicios públicos de carácter supramunicipal aquellos que, siendo de competencia de los municipios, se desarrollen ... en un ámbito superior al municipal...». Esto se refuerza y aclara cuando el art. 15 establece: »Las Diputaciones Provinciales podrán prestar servicios de carácter supramunicipal mientras los Ayuntamientos respectivos no los estén prestando». Conviene aclarar que ese «mientras los respectivos ayuntamientos no lo estén prestando» significa «mientras no los estén prestando ni aisladamente ni a través de una mancomunidad», que es otra forma de prestar servicios municipales con un ámbito territorial superior al municipio. Vid. Manuel Rebollo PUIG y Eloísa CARbonell PorRas, «La Administración local en la legislación andaluza», en Santiago MuÑOZ MACHAdO (Dir.), Tratado de Derecho municipal, Civitas, Madrid, 2. ${ }^{\text {a }}$ ed., 2003, II, pág. 2833. Más claro es aún el art. 65.c) de la Ley de Aragón 7/1999, de 9 de abril, de Administración Local que atribuye a las Diputaciones «prestar los servicios públicos que tengan carácter supracomarcal o supramunicipal, cuando su gestión no corresponda a las comarcas o no sea asumida por una mancomunidad». La misma Ley, en su art. 71 lo reitera y pone de relieve que estos servicios supramunicipales de las Diputaciones no son nada más que una forma de cooperación excepcional: «La prestación de servicios que, por su naturaleza, excedan del ámbito del municipio y en tanto no sean asumidos por una mancomunidad..., será atendida por la Diputación Provincial, previa la firma de los oportunos convenios o acuerdos de cooperación», y todavía añade: «La prestación de servicios supramunicipales, cuando sea excepcionalmente asumida por la Diputación Provincial...».

103 Vid., entre otros, Jesús LeGUINA VILLA, «La autonomía de municipios y provincias en la nueva ley básica de régimen local», Revista de Estudios de la Administración Local y Autonómica, n. ${ }^{\circ}$ 227, 1985, pág. 438.

104 Vid. Manuel J. SARMIENTO ACOSTA, Las competencias de los cabildos insulares, Ediciones del Cabildo Insular de Gran Canaria, Las Palmas, 1993, págs. 76 a 81; Tomás FonT I Llovet, «La comarca y la estructura del gobierno local», en la obra colectiva dirigida por Rafael GóMEZ-FERRER MORANT, La provincia en el sistema constitucional, Civitas, Madrid, 1991, págs. 268 y ss. 
Son también, por tanto, un instrumento que compensa las insuficiencias de los pequeños municipios y disminuye la necesidad de supresión. Más aún, en buena medida han sido vistas como una alternativa a la fusión e incorporación de municipios ${ }^{105}$.

Se ha criticado que de esta forma se desvirtúa el papel de estas entidades de segundo nivel y se convierte a los pequeños municipios en «entidades permanentemente mendicantes ante las Diputaciones provinciales $-\mathrm{u}$ organizaciones equivalentes - o ante otras instancias políticas superiores» ${ }^{106}$. Algo de cierto hay en ello, pero, aun así, es un mal menor, una alternativa preferible en muchos casos a la pura supresión municipal.

\section{Colaboración y asociacionismo entre municipios}

De otra parte, no puede infravalorarse el papel que pueden cumplir, y que de hecho están cumpliendo, las fórmulas de asociacionismo municipal voluntario para superar gran parte de los problemas de los pequeños y medianos municipios $^{107}$. Me refiero sobre todo y primeramente a las mancomunidades que son asociaciones voluntarias de municipios con personalidad jurídica de Derecho público para la gestión común de servicios u obras y cuyos órganos superiores han de ser representativos de los ayuntamientos que las forman (arts. 4.3 y 44 LRBRL). Su éxito es incuestionable. Existen en España alrededor del millar de mancomunidades que asocian aproximadamente al $75 \%$ de los municipios, pero son muy diversas entre sí, como fruto que son de los acuerdos entre los asociados. No sólo hay municipios que no pertenecen a ninguna mancomunidad - normalmente, los de más población - , sino que es perfectamente posible que un mismo municipio pertenezca a varias, incluso de distinto ámbito territorial, cada una de ellas con un objeto diferente. Aunque su regulación concreta corresponde a cada una de las comunidades autónomas, puede decirse en general que suponen una técnica flexible, maleable según las necesidades del caso y las aspiraciones de los mancomunados. De hecho, no sólo es que proliferen, sino que incluso puede afirmarse que han desbordado su configuración legal tradicional pues han pasado de estar concebidas para la gestión de algún servicio u obra concretos (principio de especialidad), a tener fines genéricos y

\footnotetext{
105 En esta dirección, es particularmente sugerente Santiago MuÑOZ MACHADO, Derecho público de las comunidades autónomas, Iustel, $2 .^{\text {a }}$ ed., 2007, II, págs. 236 a 239, que llega a presentar a la «alternativa comarcal» como un «postulado del principio de autonomía local». Con todo, es oportuno recordar que según José Luis MARTíNEZ LóPEZ-MUÑIZ, «La Administración local en Castilla y León», cit., pág. 644, las comarcas no pueden constituir un remedio al problema de los pequeños municipios de esa región: «su eventual utilidad se encuentra en otro plano, en orden, especialmente, a una descentralización de algunas funciones de las provincias o de la propia comunidad autónoma...».

106 José Luis MARTíNEZ LÓPEZ-MUÑIZ, «Cooperación y subsidiariedad intermunicipal», cit., pág. 69.

107 Esta es la vía seguida sobre todo en Italia, especialmente en algunas regiones. Vid. Tomás FONT I LLOVET, «La renovación del poder local: avances en la configuración jurídica e institucional del gobierno local», Anuario del Gobierno Local, 2001, pág. 29.
} 
asumir gran parte de las competencias de los municipios asociados ${ }^{108}$. Así, además de otras funciones, están sirviendo muy efectiva y eficazmente para solventar gran parte de los problemas del minifundismo municipal, y lo hacen no sólo con menos resistencia que la que levanta la supresión de municipios sino también con menos recelos, coste y, burocracia que las comarcas, frente a las que las mancomunidades aparecen como un cauce más natural y espontáneo.

Una especie de alternativa de Derecho privado a las mancomunidades, aunque siempre de ámbito funcional más reducido, es la creación de sociedades mercantiles cuyo capital pertenece íntegramente a varios municipio o a estos y a alguna otra entidad local (provincial o comarcal) o a la correspondiente Administración autonómica o estatal para la gestión de algún servicio público local o actuación de interés común. En el primer caso, son expresión pura del asociacionismo municipal; en el segundo son una mezcla de tal asociacionismo y de la cooperación o la colaboración entre entidades administrativas de distinto nivel.

Los consorcios, en principio, son otra cosa. Por su naturaleza, no son propiamente asociaciones de Administraciones y, menos todavía, asociaciones de municipios, sino entes institucionales creados voluntariamente por varias Administraciones de distinto nivel territorial ${ }^{109}$ para la gestión de algún servicio concreto (principio de especialidad). Por otra parte, la función más frecuente de los consorcios locales no es la colaboración recíproca e igualitaria entre distintas Administraciones sino la de canalizar la cooperación con los municipios de otra u otras Administraciones (la estatal, la autonómica, la provincial, la insular, la comarcal... $)^{110}$. Pero en la práctica, de hecho, muchas veces cumplen una función similar a la de las mancomunidades. Sucede así porque, aunque son entes institucionales, presentan también cierto carácter asociativo ${ }^{111}$; y porque hay numerosos consorcios en los que sus fundadores y miembros protagonistas son varios municipios que, difuminando el principio de especialidad, los constitu-

\footnotetext{
108 Por todos, Concepción BARRERo RodríGUEZ, en su comentario al art. 44, en la obra colectiva dirigida por Manuel ReBollo PUIG y coordinada por Manuel IZQUIERdo CARRASCO, Comentarios a la Ley Reguladora de las Bases del Régimen Local, cit., tomo I, págs. 1045-1046, donde se explica este fenómeno de las «mancomunidades evolucionadas».

109 Luis Cosculluela MonTAner, Manual de Derecho Administrativo, cit., pág. 307.

110 En la LRBRL aparecen en su art. 57 como uno de los cauces de la cooperación con las Administraciones locales y en su art. 87 donde simplemente se afirma que las «entidades locales pueden constituir consorcios con otras Administraciones públicas para fines de interés común...». Vid. Manuel REBOLLO PUIG, «Los consorcios...», cit., págs. 223 y ss.

111 Hasta tal punto es así que, por ejemplo, en la Ley andaluza 7/1993 aparecen regulados bajo el título «De las mancomunidades y otras asociaciones locales». Por eso no es de extrañar que se haya llegado a calificarlas como «personificaciones instrumentales de naturaleza corporativa» o como «corporaciones instrumentales». La primera calificación es de Juan Alfonso SANTAMARÍA PASTOR, Fundamentos de Derecho Administrativo, Centro de Estudios Ramón Areces, Madrid, 1988, pág. 1199; la segunda de Eva NIETO GARRIDO, Comentario al artículo 87, en la obra dirigida por Manuel REBOLlo PUIG y coordinada por Manuel IZQUiERdo CARRASCo, Comentarios a la Ley Reguladora de las Bases del Régimen Local, cit., II, pp.2337-2338.
} 
yen para la gestión común de muchas de sus competencias, aunque con la presencia secundaria de otra u otras Administraciones (sobre todo, diputaciones provinciales) que de este modo cooperan conjunta y simultáneamente con varios municipios ${ }^{112}$. Así, quedan a caballo entre instrumento para articular la cooperación con los pequeños municipios y para el asociacionismo de éstos. Por una y otra faceta son un remedio perfecto y habitual para paliar las disfunciones del micromunicipalismo ${ }^{113}$. Tienen además la ventaja, que no quiero dejar de destacar aquí, de que caben los llamados consorcios transfroterizos que pueden utilizarse para la gestión de los servicios públicos locales en el marco de convenios de cooperación transfronteriza en que participen entidades locales españolas y de acuerdo con convenios internacionales ratificados por España (art. 87.2 LRBRL), como el firmado con Portugal el 3 de octubre de 2002, consorcios que son posibles con composición exclusivamente municipal, aunque esto normalmente debería llevar a hablar de mancomunidades ${ }^{114}$.

La colaboración entre municipios para la prestación de servicios puede adoptar otras formas, sin que ni siquiera sea siempre imprescindible la creación de una persona jurídica. Hay incluso algunas vías previstas hace muchos años en la legislación. Piénsese en que el Reglamento de Servicios de las Corporaciones Locales de 1955 admite que un municipio concierte con otro la prestación de un determinado servicio que incluso puede localizarse fuera de su término (arts. 143 y 145). Pero hay también recientes previsiones legales que dan idea de las posibilidades para superar algunas dificultades de los pequeños municipios. Bastará traer aquí la Ley Orgánica 16/2007 complementaria de la Ley de desarrollo sostenible del medio rural: «En los supuestos en los que dos o más municipios limítrofes ... no dispongan separadamente de recursos suficientes para la prestación de los servicios de policía local, podrán asociarse para la ejecución de las funciones asignadas a dichas policías...» con el sólo requisito de obtener la autorización de la comunidad autónoma o del Estado.

Las comunidades autónomas no sólo han explotado y perfeccionado estas posibilidades voluntarias sino que han explorado otras que igualmente abundan en el asociacionismo y la colaboración entre municipios aumentando la gama de técnicas y flexibilizando, en suma, su instrumentación jurídica. Ejemplo de ello son las previstas en la legislación catalana con la denominación de «comunida-

\footnotetext{
112 Sobre esta utilización de los consorcios, con ejemplos de ello, Manuel REBOLLO PUIG, «Los consorcios...», cit., pág. 236.

113 Todo ello, desde luego, sin perjuicio de que los consorcios, incluso específicamente los consorcios locales, cumplen otras muchas funciones alejadas de lo que aquí nos interesa. Puede incluso que formen parte del consorcio, no ya entes públicos, sino también entes privados sin ánimo de lucro. En este caso, son también un instrumento para canalizar la colaboración de privados en la realización del interés general y de integración del llamado «tercer sector».

114 Eva NiETo GARRIDO, Comentario al artículo 87, en la obra dirigida por Manuel RebOLLO PUIG y coordinada por Manuel IZQUIERDO CARRASCO, Comentarios a la Ley Reguladora de las Bases del Régimen Local, cit., II, págs. 2348-2349.
} 
des de municipios» (arts. 123 a 132 TR de la Ley Municipal y de Régimen Local de Cataluña): no tienen personalidad jurídica, pero sí órganos propios que pueden incluso contratar, cuyos acuerdos vinculan a todos los municipios agrupados y de los que responden solidariamente. Con carácter temporal o indefinido, pueden incluir a municipios no limítrofes, pero siempre con un objeto determinado ${ }^{115}$. Más interesante incluso es lo establecido en la Ley Foral de la Administración Local que, como régimen especial para municipios rurales de menos de 5.000 habitantes, idea una nueva figura, la de los «distritos administrativos», en la que los municipios navarros pueden libremente delegar gran parte o incluso «todas sus competencias para la realización de actividades y prestación de servicios públicos». Su órgano de gobierno es la «asamblea» compuesta por un concejal de cada uno de los municipios, aunque con voto ponderado en función del respectivo número de habitantes. Su principal diferencia con las mancomunidades es que queda ya por completo excluida la especialidad de sus funciones y competencias, de manera que los municipios pueden resultar muy menguados en su actividad directa ${ }^{116}$. Estamos, por tanto, ante una figura que en la práctica se aproxima a la fusión y que, por eso mismo y por ser voluntaria y dejar subsistentes a los municipios, puede presentarse como una alternativa a ésta menos restrictiva de la autonomía y, por ende, preferente.

En todo lo expuesto hasta aquí, la voluntad de los municipios afectados es necesaria y determinante. Si acaso, algunas normas sectoriales dan un paso más pues, aunque mantienen la voluntad de los municipios como requisito esencial, constriñen de alguna forma su libertad condicionando a la creación de un ente asociativo la posibilidad de acceder a algunas ventajas. Es clásico el ejemplo que ahora recoge el art. 89 de la Ley de Aguas: «El otorgamiento de las concesiones para abastecimiento a varias poblaciones estará condicionado a que las Corporaciones Locales estén constituidas a estos efectos en Mancomunidades, Consorcios u otras entidades semejantes, de acuerdo con la legislación por la que se rijan, o a que todas ellas reciban el agua a través de una misma empresa concesionaria». Pero hay otros supuestos dispersos en los más diversos sectores del ordenamiento ${ }^{117}$.

115 Vid. Ferrán TORRES CoBAS, «Perversiones y novedades de la cooperación municipal», Anuario del Gobierno Local, 2003, págs. 281 a 284.

116 Vid. José Antonio RAZQUIN LIZARRAGA, «Las entidades locales de Navarra», en Martín RAZQUIN LIZARRAGA y Francisco Javier EnÉRIZ OlaEchea (Dirs.), Derecho local de Navarra, Gobierno de Navarra, Pamplona, 2005, págs. 168 y ss.

117 Así ocurre, por ejemplo, con las televisiones municipales. La Ley estatal 41/1995 de Servicio de Televisión Local por Ondas Terrestres con carácter general prevé otorgar un canal para los municipios de más de 100.000 habitantes, pero luego admite en su art. 3.3 que se reserven canales múltiples para atender conjuntamente las necesidades de varios municipios colindantes cuya población de derecho total sea de más de 25.000 habitantes o cuya cobertura incluya a todos los municipios en un radio de al menos $25 \mathrm{Km}$. Su art. 9 sólo dice que el programa será atribuido conjuntamente a todos los municipios. Pero algunas comunidades autónomas han dado el salto que nos interesa. Es el caso de Andalucía. El Decreto andaluz 1/2006, de 10 de enero, que regula el régimen jurídico de las televisiones locales por ondas terrestres, dispone que «en el caso en que sean varios los municipios solicitantes en una demarcación establecida en el Plan Técnico Nacional ..., el progra- 
En esta línea de mantener formalmente la voluntariedad de la colaboración $\mathrm{y}$, al mismo tiempo, tratar de vencer la resistencia de los municipios reticentes, es sugerente el art. 83.8 de la Ley de Administración Local de Aragón: «En los expedientes de supresión de municipios podrá tenerse en cuenta la circunstancia de haberse rechazado previamente el establecimiento y prestación de servicios obligatorios a través de fórmulas asociativas». A buen entendedor pocas palabras bastan, y este art. 83.8 bastará para comprender que no aceptar una mancomunidad o similar puede comportar, a la postre, la supresión del municipio.

\section{Referencia particular a la Ley de Desarrollo Sostenible del Medio Rural}

En la legislación estatal reciente merece ser destacada la Ley 45/2007, de 13 de diciembre, de Desarrollo Sostenible del Medio Rural ${ }^{118}$. En ella se define al «municipio rural de pequeño tamaño» como el que «posea una población residente inferior a los 5.000 habitantes y esté integrado en el medio rural», esto es, en «el espacio geográfico formado por la agregación de municipios o entidades locales menores definido por las Administraciones competentes que posean una población inferior a 30.000 habitantes y una densidad inferior a los 100 habitantes por Km cuadrado». Y para estos municipios se prevén en el marco del «programa de desarrollo rural sostenible» una larga serie de actuaciones. $\mathrm{Mu}$ chas de ellas conciernen exclusivamente a las Administraciones estatal o autonómicas. Pero otras se refieren a servicios de competencia municipal y comportan sistemas cooperación con estos municipios rurales y hasta de colaboración entre ellos mismos. Hay un propósito de intensificar el uso de los distintos medios que hemos ido viendo. Citemos algunos ejemplos:

- «Implantar servicios mancomunados o por zona rural de recogida selectiva de residuos, su gestión ambiental...».

\footnotetext{
ma o programas reservados para la gestión directa municipal será atribuido conjuntamente a los municipios interesados, en la forma prevista en el art. 8 del presente Decreto» (art. 7.4). Y según ese art. 8.1 «en el supuesto previsto en el apartado 4 del art. 7, y con carácter previo al otorgamiento de la concesión, los municipios de una misma demarcación que accedan a la explotación de un programa de televisión local en una determinada demarcación, habrán de constituir una sociedad mercantil con capital exclusivamente público y participada por los mismos, cuyo objeto social sea la gestión directa del servicio, o adoptar cualquier otra forma de gestión directa prevista en el art. 85.2.A) de la LRBRL. No obstante lo anterior, y en el supuesto de que no se alcanzase un acuerdo para la constitución de una entidad gestora entre la totalidad de los municipios solicitantes de la gestión... la concesión se otorgará a la entidad integrada por aquellos municipios que, alcanzando un acuerdo, sumen una población censada que represente más de las tres quintas partes del total de la demarcación. En caso de no alcanzarse un acuerdo ni por la totalidad de los municipios ni por los que alcancen los tres quintos de la población, no será otorgada la concesión correspondiente.»

118 Sobre su relación con la política agraria común y, en concreto, con su «segundo pilar», vid. Manuel RODRÍGUEZ PORTUGUÉS, «Competencias sobre agricultura, ganadería, pesca, acuicultura y marisqueo», en Santiago Muñoz Machado y Manuel Rebollo Puig (Dirs.), Comentarios al Estatuto de Autonomía para Andalucía, Thomson/Civitas, Madrid, 2008, págs. 434-435.
} 
- «Apoyar la dotación de los servicios públicos municipales de prestación obligatoria en los núcleos urbanos del medio rural, su mantenimiento y mejora ... Se favorecerá específicamente la prestación coordinada de servicios públicos entre municipios cercanos».

- «La implantación y ejecución de planes de gestión integral de recursos hídricos por zonas rurales o mancomunidades de municipios, que contemplen la gestión conjunta del ciclo integral del agua, las medidas necesarias para las situaciones de escasez y sequía y las acciones de protección contra posibles avenidas e inundaciones».

Hay latente un abandono de las fusiones e incorporaciones municipales en tanto que si comportaran crear nuevos municipios con más de 5.000 habitantes se perderían parte de los beneficios previstos por esta Ley.

\section{Agrupaciones forzosas de municipios}

Pero es que, además, se han admitido tradicionalmente agrupaciones forzosas de municipios y se pueden seguir aceptando. Nos referimos, claro está, a agrupaciones de municipios obligatorias (a diferencia de las mancomunidades y otras entidades de carácter voluntario) para crear un ente no territorial (a diferencia de las comarcas) que los incluye a todos pero que (a diferencia de la fusión) no los suprime: mantienen su personalidad y su sustantividad.

La legislación de régimen local inmediatamente anterior a la Constitución las preveía con amplitud, sobre todo en el caso de los municipios de menos de 5.000 habitantes ${ }^{119}$. Y lo que debemos ahora resaltar es que la STC 4/1981, de 2 de febrero, confirmó su plena constitucionalidad, entre otras cosas porque la misma Constitución, en su art. 141.3, habla de agrupaciones de municipios sin que haya razón para entender que sólo se refiere a las comarcas: de acuerdo con el art. 141.3 CE «que guarda estrecha conexión con el 152.3 de la propia Constitución, hay que estimar que la autonomía local está limitada por la posibilidad de crear agrupaciones de municipios. Sin prejuzgar el alcance exacto de los preceptos de la Constitución aludidos, es claro que no se opone a la misma la creación de agrupaciones con fines limitados, que no tienen el carácter de entes territoriales». Desde este punto de vista, el precepto entraña la consagración de

\footnotetext{
119 La norma de referencia es el Texto Articulado parcial de la Ley 41/1975, aprobado por Real Decreto 3046//1977 que claramente optó por esta vía de las agrupaciones forzosas frente a la supresión pura y simple Había dos grandes supuestos de agrupación forzosa. El primero en relación con los pequeños de menos de 5.000 habitantes de los que se decía que «habrán agruparse forzosamente en los casos y para los fines que se determinan ... sin pérdida de su personalidad jurídica». En concreto, se debían agrupar para sostener la secretaría municipal y el personal común si tenían menos de 2.000 habitantes, así como para la prestación de los servicios públicos esenciales si carecen de los recursos económicos para ello. El segundo supuesto se refería a los casos en que hubiera que ejecutar obras o servicios subvencionados o delegados por el Estado.
} 
un límite a la autonomía municipal que sin esta consagración expresa sería más dudosamente admisible y que, incluso con ella, debe aparecer como una medida justificada y proporcionada. Así entendió la STC citada que lo era la regulación antes existente sobre estas agrupaciones forzosas: «Las causas previstas para esta creación por la Ley aparecen justificadas, ya que tienden a superar la insuficiencia de medios de los Municipios - para el sostenimiento de la Secretaría municipal y, en su caso, del personal común, o para la prestación de servicios públicos considerados esenciales por la Ley-, o a facilitar la ejecución de obras y servicios subvencionados o delegados por el Estado».

No nos detendremos en el hecho de que la LRBRL no previó nada de esto; tampoco en valorar que en el TRRL sólo aparece la agrupación forzosa para el sostenimiento de la secretaría; ni que, tal vez por ello, muchas de las comunidades autónomas sólo han previsto agrupaciones municipales forzosas con ese objetivo, extendiéndolo si acaso, al sostenimiento de otro personal ${ }^{120}$. Porque lo capital para nuestro propósito es que el TC admitió la constitucionalidad de aquella regulación que preveía con bastante amplitud las agrupaciones forzosas; que la consideró una restricción a la autonomía pero compatible con la Constitución y admisible en cuanto tenía causas justificadas. Esto, que además ha quedado reforzado en algunos nuevos Estatutos de Autonomía ${ }^{121}$, suministra un fundamento más seguro del que se tiene, por ejemplo, en Francia, donde, no obstante, han proliferado distintas formas de agrupación forzosa para paliar las carencias de sus 36.000 municipios $^{122}$. En principio, por tanto, nada se opone a que igual camino pudiera emprenderse aquí. Al contrario. Y, además, algunas comunidades autónomas las han regulado sin que se hayan suscitado problemas de constitucionalidad. Una vez más, la Ley Foral de Administración Local de Navarra nos suministra una buena prueba al prever agrupaciones forzosas con órganos de gobierno propios representativos de los ayuntamientos agrupados y creadas normalmente por ley que fijará para cada caso sus competencias y recursos (art. 46).

120 Ley de Galicia 5/1997, arts. 168 a 170; Ley de Murcia, arts. 54 y ss); Ley de Madrid, art. 78 a 80; etc.

121 Por ejemplo, el art. 94 del nuevo Estatuto de Andalucía establece expresamente que «una ley regulará las funciones de las áreas metropolitanas, mancomunidades, consorcios y aquellas otras agrupaciones de municipios que se establezcan...». Vid. José Luis RIVERO YSERN, «El régimen local en el nuevo Estatutos de Autonomía de Andalucía. Reglas sustantivas y distribución de competencias», en Santiago MuÑOZ Machado y Manuel Rebollo Puig (Dirs.), Comentarios al Estatuto de Autonomía para Andalucía, cit., pág. 857. También art. 25.4 del nuevo Estatuto de Castilla y León. Por el contrario, el nuevo Estatuto catalán puede suponer una dificultad pues, de acuerdo con sus arts. 83 y 93, parece que, salvo la comarca y las áreas metroplitanas, todas las entidades supramuicipales han de basarse en la voluntad de los municipios afectados.

122 Jean-Louis AUTIN, «La reforma de la cooperación intermunicipal ...», cit., págs. 241 y ss. in totum; en págs. 251-252 explica los débiles argumentos con que se cuenta en Francia para justificar la constitucionalidad de las agrupaciones forzosas de municipios y la restricción a la «libre administración» que suponen. También es problemática en Portugal la admisión de esas agrupaciones o «federaçoes» obligatorias. Vid. Diogo Freitas Do Amaral, Curso de Direito Administrativo, Coimbra, 1988, pág. 493. 
Sería absurdo, por otro lado, que admitiendo gran parte de la doctrina y el propio TC que cabe la radical supresión de municipios sin que a ello se oponga la autonomía local, se entendiera que no es posible la simple agrupación forzosa: sería ya la expresión máxima del absurdo de dar a la autonomía local un contenido desorbitado en tanto subsiste un municipio, y negarle cualquier relevancia en cuanto a esa misma subsistencia. Pero, conforme a lo que aquí se ha defendido, el resultado es coherente y armonioso: la autonomía no impide por completo ni la supresión de municipios ni, menos aún, su agrupación forzosa; pero ello siempre que sea una medida necesaria para los intereses públicos y aparezca como proporcionada. Cuando la agrupación forzosa sea suficiente, como quiera que es menos radical, debe considerarse preferente a la supresión.

\section{Réplicas y dúplicas sobre estas soluciones alternativas a la supresión}

Se podrá decir, tal vez, que lo que aquí se propugna es mantener formalmente el nombre de municipio para designar un revestimiento jurídico ínfimo y bastante distinto al de los medianos y grandes. Un municipio con una organización rudimentaria, con un régimen simplificado, con menos competencias ¿Y qué? Bien está si esto, que a fin de cuentas no es más que llevar la tantas veces propugnada diversidad hasta sus últimas consecuencias, consigue armonizar las aspiraciones ciudadanas y las necesidades de la organización general. Se dirá tal vez que lo que aquí se preconiza es dejar municipios casi sin vida, vida, además, con respiración asistida y en parte insuflada y mantenida artificialmente por otras Administraciones y, aun así, compartida con los municipios limítrofes gracias a asociaciones voluntarias o hasta forzosas. Y se podrá objetar también que estos municipios, a veces, parecerán más bien una especie de circunscripción electoral para elegir a los representantes en organizaciones supramunicipales; incluso que eso contradice un principio fundamental de democracia local ${ }^{123}$. Cierto. Pero en muchos casos puede ser mejor solución que la del exterminio de infinidad de municipios que quieren seguir administrando por sí sus bienes, decidir si se coloca o no una terraza de un bar o un puesto de helados, que quieren conservar su cementerio y gestionarlo ..., que temen, quizás no sin alguna base, que verán degradados sus servicios si pasan a disolverse en una entidad mayor con una capitalidad absorbente, que quieren, en suma, conservar su identidad y

\footnotetext{
123 A este respecto es certera y aguda la observación de Antonio Cândido de OLIVEIRA, «La creación de municipios en Portugal...», cit., pág. 65: «esta trasferencia de competencias de los municipios al ente asociativo conlleva la vulneración de un principio fundamental de la autonomía local, rectius, de la democracia local, cual es la existencia en todo ente local encargado de la gestión de los asuntos de la colectividad local de una asamblea representativa directamente elegida por los ciudadanos» porque se sustituye por «una elección indirecta». En la misma dirección Jean de SAVIGNY, ¿El Estado contra los municipios?, cit., págs. 230231 y 239-240, explica como estos entes de segundo nivel «escapan al control de los ciudadanos», son una «perniciosa fórmula para la democracia»y, con su «huella tecnocrática», «provocan el desinterés del ciudadano por los asuntos municipales».
} 
su expresión jurídica. Se trata de hacer un traje a la medida de cada comunidad local; de que, como dijo Morell, el peso de la púrpura no les impida sostenerse en pie ${ }^{124}$; de que haya opciones entre ese traje grande pesado y la total desnudez. Se objetará, entonces, que para ello existen las entidades inframunicipales, las entidades locales menores, llámeseles como se les llame, que suministran una vestidura suficiente. Así será, en efecto, en muchos casos, y más puede serlo si se hace una regulación adecuada de ellas que las consolide y dignifique. Así lo acepto porque nada de lo que se ha defendido supone negar la posibilidad, la conveniencia y hasta la necesidad de suprimir ciertos municipios, no sólo inviables sino mortecinos. Pero no lo será en otros muchísimos supuestos en los que quedará más a la medida ese traje del pequeño municipio que, por otra parte, no supondrá ningún daño para el interés público de suerte que no será realmente imprescindible ni, por tanto, constitucional su supresión.

\section{REFLEXIONES FINALES}

Con nada de lo anterior se defiende el mantenimiento a ultranza del mapa municipal español como si fuera una foto fija. Eso no tiene sentido. Pero sí que me parece defendible que, partiendo de la situación actual, sólo se pretenda superar disfunciones concretas y adaptar ese mapa a la evolución demográfica, social y geográfica según su propia lógica en la que se acepta con normalidad la existencia de pequeños municipios; que se renuncie a la reducción drástica y general de municipios hasta alcanzar un mapa municipal radicalmente diferente, como en otros países. Me gusta lo que dicen casi en iguales términos la Ley de Administración de la Rioja y la de Aragón cuando señalan como finalidad de la alteración de municipios, junto con otras, la de «adaptar los términos municipales a la realidad física, social y cultural de los núcleos de población, de forma que permitan la representación de una colectividad con conciencia de tal y con unos específicos valores históricos y tradicionales». Quizá parezca demasiado grandilocuente para referirse a estos pequeños municipios, pero creo que está bien orientado. La potestad de supresión de municipios debe estar al servicio de estas ideas y, por tanto, aniquilar los municipios que ya no tengan ese sustrato social pero también, al mismo tiempo, tender a respetar en la medida de lo posible esas realidades municipales que sí lo tengan, aunque sean pequeños, aunque no sean la forma más racional de organización territorial, aunque haya fórmulas más eficientes. Ello, salvo exigencias imponderables de interés público que no puedan satisfacerse con las muchas fórmulas alternativas y menos drásticas que hemos ido viendo. Es esto, según se ha explicado, lo más conforme a la autonomía local garantizada por la Constitución.

Después de todo, la organización administrativa no tiene que estar sólo al servicio de la eficacia y de la eficiencia como si de una empresa privada se

124 Luis MORELl OCAÑA, La Administración local, cit., pág. 33. 
tratara, ni debe ser siempre y por completo fruto de la pura y fría racionalidad. También tiene que dar cabida a la historia, a la pequeña historia, incluso; tal vez hasta deba hacer algún lugar a los sentimientos, siquiera sea para que no exploten de forma irracional. También es una forma de dar expresión jurídica a una realidad social tan arraigada como puede ser un pueblo. Es más, por eso existen los municipios, todos los municipios, y por eso tienen garantizada su autonomía, aunque se probara que una centralización radical supondría una gestión más eficaz de los asuntos y recursos públicos.

«Más de una vez, al pasear lentamente por las calles de la tarde, me ha sacudido el alma, con una violencia súbita y perturbadora, la extrañísima presencia de la organización de las cosas. No son las cosas naturales las que tanto me afectan, las que tan poderosamente me provocan esta sensación: son, por el contrario, los trazados de las calles, los letreros, las personas vestidas y hablando, los empleos, los diarios, la inteligencia de todo. O, mejor dicho, el hecho de que existan trazados de calles, letreros, empleos, hombres, sociedad, todo entendiéndose y continuando y abriendo caminos. Reparo en el hombre directamente, y veo que es tan inconsciente como un perro o un gato... Y entonces, tanto o más que la existencia de organismos, tanto o más que la existencia de leyes rígidas físicas o intelectuales, se me revela mediante una luz evidente la inteligencia que crea e impregna al mundo». Me conmueve este pasaje del Livro do desassossego en el que Pessoa ve en el funcionamiento social lo que más frecuentemente se revela a otros ante el de la naturaleza. Seguramente es excesivo traer aquí estas reflexiones pessoanas para ver algo similar en esos pequeños municipios. Pero quizás, más modestamente, se me acepte recordar que el ordenamiento jurídico forma un complejo y delicado sistema de organización que no se agota en las normas creadas por la voluntad de los poderes públicos ni se puede transformar al gusto de estos o de su supuesta racionalidad, que el ordenamiento es, él mismo, en parte, un fruto social o hasta se identifica con la estructura y organización de la sociedad. Es, en la conocida teoría de Santi Romano, organización, estructura, posición de un ente social como tal y posición en relación con sus miembros. Hauriou dijo que el carácter común de las instituciones «reside en el hecho de que su duración no depende de la voluntad subjetiva de determinados individuos. Por más que ciertas personas, por ejemplo, algunos legisladores, tratasen de destruir tal o cual institución, ella viviría y el propósito destructor resultaría impotente... No sólo nacen espontáneamente, sino que renacen; son cabezas cortadas que vuelven a brotar como las de la hidra mitológica del lago de Lerma». Así, nuestro ordenamiento es el de esos más de 8.000 municipios, el de esos municipios pequeños que son verdaderas instituciones y sobre las que están construidas otras muchas, infinidad de relaciones, normas y todo el sistema en lo que tiene de menos artificioso. No sé si vale la pena someterlo a un terremoto, sacrificarlo en el altar de la eficacia y eficiencia administrativas y, menos aún, en culto de una supuesta racionalidad que impone que todos los municipios hayan de ser medianos o grandes, aunque los pueblos sean pequeños, para que 
les venga bien el traje que les hemos hecho sin tomarles medidas. Tal vez, si acaso, eso debe hacerse con extremada cautela, con exquisito tiento y lentamente, como resultado de un largo camino de pequeños pasos cada uno de los cuales sea el resultado de un proceso natural de manera que, en efecto, sólo certifiquemos la defunción de los municipios realmente muertos. De lo contrario, estaremos creando municipios grandes pero artificiales e inservibles en los que la fuerza institucional esté en sus núcleos de población en los que la cabeza de la hidra rebrotarán sin encontrar forma jurídica. 